Dr DRAGAN CVETKOVIĆ, muzejski savetnik

Muzej žrtava genocida

Beograd, Republika Srbija

vecadzigy@yahoo.com

originalan naučni rad

UDK: 94:341.485(497.5)"1941/1945"

primljeno: 25. jun 2018.

$314.117-058.65(497.5) " 1941 / 1945^{\prime \prime}$

prihvaćeno: 21. novembar 2018.

$343.819 .5(497.5) " 1941 / 1945^{\prime \prime}$

https://doi.org/10.29362/ist20veka.2019.1.cve.93-120

\title{
GEOSTATISTIČKA ANALIZA LJUDSKIH GUBITAKA U KONCENTRACIONOM LOGORU JASENOVAC
}

APSTRAKT: Rad predstavlja pokušaj da se na osnovu delimično revidiranog popisa „Žrtve rata 1941-1945“ iz 1964. godine prikaže uloga koncentracionog logora Jasenovac u uništavanju naroda iz različitih delova Nezavisne Države Hrvatske. Na osnovu dostignutog rezultata u procesu revizije poimeničnog popisa urađen je proračun ukupnih gubitaka civila Jugoslavije, NDH i njenih regiona, te gubitaka u logoru Jasenovac. Pretrpljeni gubitak u Jasenovcu komparativno je posmatran kroz prizmu opšteg stradanja civilnog stanovništva NDH tokom rata u svim njenim delovima, a sve je upoređeno sa demografskom strukturom stanovništva NDH i njenih regiona.

KLJUČNE REČI: Nezavisna Država Hrvatska, civili, koncentracioni logor, Jasenovac, Srbi, Jevreji, Romi, Hrvati, Muslimani, stanovništvo, regioni, gubici, žrtve

Stradanje civilnog stanovništva u koncentracionim logorima tokom Drugog svetskog rata predstavljalo je značajan segment ukupnih pretrpljenih ljudskih gubitaka Jugoslavije, pa je kao takvo bilo predmet istraživanja jugoslovenske istoriografije, kao i istoriografija država naslednica. Najveći deo radova je, direktno ili indirektno, posvećen logoru Jasenovac, ali kvantitet objavljenih radova nije praćen jednakim kvalitetom, ${ }^{1}$ a svi su uticali na stvaranje predstave

\footnotetext{
${ }^{1} \mathrm{O}$ obimnom opusu radova o Jasenovcu (ali i drugim logorima u NDH) do 2.000. godine videti: Jovan Mirković, Objavljeni izvori i literatura o jasenovačkim logorima (Banja Luka-Beograd: GrafoMark - MŽG, 2000); kasnije: Nataša Mataušić, Jasenovac 1941.-1945., Logor smrti i radni logor (Jasenovac-Zagreb: JSUP Jasenovac, 2003); Davor Kovačić, „Iskapanja na prostoru koncentracijskog logora Stara Gradiška neposredno poslije završetka Drugog svjetskog rata i procjene broja žrtava“, Srinia Slavonica, br. 3 (2003), 500-520; Tea Benčić Rimay, ur., Spomen područje Jasenovac - katalog-monografija (Jasenovac: JUSP Jasenovac, 2006); Nihad Halilbegović, Bošnjaci u Jasenovačkom logoru (Sarajevo: Vijeće kongresa bosanskih intelektualaca, 2006); Antun Miletić, Koncentracioni logor Jasenovac, knjiga IV (Jagodina: Gambit, 2007); Здравко Антонић, ур., Јасеноваи, зборник радова (Бања Лука: ЈУСП Доња Градина, 2007); Србољуб Живановић, Јасеновац. Одабрани радови, члании, интервјуи, говори и дискусије (Београд: Српска
} 
o logoru koja, često, nije odgovarala stvarnoj slici. Sveukupno gledano, ocene o ukupnim gubicima, te ocene o broju stradalih u Jasenovcu su varirale, menjale se tokom godina i do sada je to ostalo otvoreno pitanje o kome se i dalje vode polemike u struci i široj javnosti. ${ }^{2}$

$\mathrm{Na}$ utvrđivanje broja stradalih Jugoslavije $u$ ratu negativno je uticala dugogodišnja ideološka predstava o Drugom svetskom ratu, koja je sve jednostrano posmatrala kroz kontekst socijalističke revolucije i njenog veličanja. Iako je o ratnim žrtvama, prvenstveno o onim koje su podnete u partizanskom pokretu, govoreno da su temelj na kome počiva država i smatrane su zalogom za postojanje odnosno opstanak države i sistema, socijalistička Jugoslavija nikada nije sačinila celovit popis stradalih tokom Drugog svetskog rata. ${ }^{3}$ Usled nedostatka približno tačnih podataka otvoren je prostor za raznovrsna nagađanja, svojatanja žrtava, manipulacije, kako naučne tako i političke, pa i za stvaranje novih mitova. Država je 1964. godine pokušala da sprovede popis stradalih na celoj svojoj teritoriji. Popisom ,Žrtve rata 1941-1945“ iz 1964. godine je utvrđeno da je na teritoriji Jugoslavije stradalo 597.323 osoba, ${ }^{4}$ od kojih je 134.464 stradalo u internaciji $(22,51 \%){ }^{5}$

књига, 2008); Vladimir Markoci i Vladimir Horvat, Ogoljela laž logora Jasenovac (Zagreb: Emil Čić, 2008); Jaša Almuli, Jevreji i Srbi u Jasenovcu (Beograd: Službeni glasnik, 2009); Slavko Goldstein i Ivo Goldstein, Jasenovac i Bleiburg nisu isto (Zagreb: Novi Liber, 2011); Dejan Motl i Đorđe Mihovilović, Zaboravljeni. Knjiga o posljednjim jasenovačkim logorašima (Jasenovac Zagreb: JUSP Jasenovac, 2015); Vladimir Horvat i drugi, Jasenovački logori - istraživanja (Zagreb: Društvo Jasenovački logori, 2015); Slavko Goldstein, Jasenovac - tragika, mitomanija, istina (Zagreb: Fraktura, 2016); Василије Крестић и Мира Радојевић, Јасеноваи (Београд: Српска академија наука и уметности, 2017); Adriana Benčić i drugi, ur., Jasenovac - Manipulacije, kontroverze i povjesni revizionizam (Jasenovac: JUSP Jasenovac, 2018); Igor Vukić, Radni logor Jasenovac (Zagreb: Naklada Pavičić, 2018). O broju stradalih u logoru Jasenovac videti: Narcisa Lengel-Krizman, Genocid nad Romima (Jasenovac-Zagreb: JSUP Jasenovac, 2003); Igor Graovac i Dragan Cvetković, Ljudski gubici Hrvatske 1941.-1945. godine: pitanja, primjeri, rezultati.... (Zagreb: Dijalog, 2005), 72-75, 97; Dragan Cvetković, „Страдање цивила Независне Државе Хрватске у логору Јасеновац“, Токови историје, br. 4, (2007), 153-168; Tea Benčić Rimay, ur., Jasenovac, žrtva je pojedinac - Poimenični popis žrtava koncentracijskog logora Jasenovac 1941.1945 (Jasenovac: JUSP Jasenovac, 2007); Antun Miletić, Ubijeni u koncentracionom logoru Jasenovac 1941-1945 (Jagodina: Gambit, 2011); Vladimir Geiger, „Brojidbeni pokazatelji o žrtvama logora Jasenovac, 1941.-1945 (procjene, izračuni, popisi)”, Časopis za suvremenu povijest, 45, br. 2, (2013), 211-242; Душан Никодијевић, „Прилог утврђивању броја жртава система логора Јасеновац 1941. године“, Годишъак за истраживање геночида, бр. 8, (2016), 169-213; Душан Никодијевић, „Бројеви жртава у концентрационом логору Јасеновац 1942. године према исказима преживелих сведока“, Годишњак за истраживање геноиида, бр. 9, (2017), 95117; Душан Никодијевић, „Бројеви жртава у концентрационом логору Стара Градишка 1942. године према исказима преживелих сведока“, Годишњак за истраживање геноцида, бp. 10, (2018), 127-155.

${ }^{2}$ Opširnije u: Vladimir Geiger, „Ljudski gubici Hrvatske u Drugom svjetskom ratu koje su prouzročili „okupatori i njihovi pomagači“ Brojdbeni pokazatelji (procjene, izračuni, popisi)“, Časopis za suvremenu povijest, 43, br. 3, (Zagreb, 2011), 699-749.

${ }^{3}$ Opširnije videti: Nenad Lajbenšperger, „Presenting and Establishing the Number of Yugoslav Casualites of World War II from Liberation until 1951“, Токови историје, бр. 3 (2017), 143-164.

${ }^{4}$ Popis je urađen za tadašnju teritoriju Jugoslavije, što znači da su u nju uračunati i stradali sa teritorija pripojenih posle Drugog svetskog rata. Odbijanjem broja stradalih sa teritorija priključenih Jugoslaviji nakon 1945. godine dobija se broj stradalih sa teritorije Kraljevine Jugoslavije 
Pored glavnog pitanja koliko je stradalih u Jasenovcu, značajno pitanje za istraživače je šta pokazuju rezultati popisa, odnosno kakva je unutrašnja struktura stradalih u logoru, te u kakvim su oni odnosu sa ukupnim gubicima civila na teritoriji Nezavisne Države Hrvatske (NDH). Iako je nepotpun i uz sva ograničenja koja kao takav nosi, ${ }^{6}$ popis ,ZZrtve rata $1941-1945 “$ je, po podacima

koji iznosi 580.981. Žrtve rata 1941-1945. Rezultati popisa (Beograd: Savezni zavod za statistiku, 1966, reprint 1992), 27-39.

${ }^{5}$ Zbog ideološke opterećenosti sa realizacijom se krenulo iz pogrešnih osnova, a i sama metodologija izrade popisa je bila manjkava. Popisna komisija je utvrdila da je učinjen čitav niz propusta pri izradi popisnika, te zaključila da je njime obuhvaćeno $56-59 \%$ lica od onih koje je trebalo obuhvatiti popisom. Popisna komisija je proračunala da bi popisom trebalo da se obuhvati 1.016.000 do 1.066.000 stradalih osoba. Procena pretrpljenih gubitaka je izvršena u Saveznom zavodu za statistiku uz stručnu saradnju dr Dušana Breznika, upravnika Centra za demografska istraživanja. U broj koji je trebalo obuhvatiti popisom nije uračunato procenjenih oko 50.000 stradalih kvislinga, kao ni oko pretpostavljenih 40.000 Roma i Jevreja ,za koje nije imao ko da pruži podatke“, iz čega proizilazi da je u Jugoslaviji u ratu ukupno stradalo između 1.106.000 i 1.156 .000 osoba, što znači da je popisom bilo obuhvaćeno 51,7-54\% stvarno stradalih iz Jugoslavije. Novija demografska istraživanja, kao i analiza rezultata ovog popisa, upućuju na to da za polaznu tačku u istraživanjima treba uzeti procenu broja stradalih koja se kreće između 1.070 .000 i 1.120 .000 osoba, odakle sledi da je popisom obuhvaćeno 53,3-55,8\% stradalih, što je uzeto kao osnova za proračun u ovom radu. Proračunati broj za teritoriju Kraljevine Jugoslavije iznosi između 1.042.000 i 1.092 .000 ukupno stradalih. U ove brojke nisu uračunati stradali u komunističkim represalijama nakon 15. maja 1945. od kojih je značajan deo, svakako, izgubio život kao posledica svoje angažovanosti u ratu. Žrtve rata..., 5-23. Pošto je popis stradalih prvenstveno sačinjen radi naplate ratne štete od Nemačke, a dobijeni broj stradalih u ratu bio je daleko od očekivanog i do tada važećeg broja 1.706.000, odlučeno je da se stavi zabrana na njegovo korišćenje i sav materijal je predat Arhivu Jugoslavije na čuvanje. Zabrana je trajala gotovo 30 godina, do 1992. Gubitak vremena je smanjio mogućnost utvrđivanja pravog broja stradalih zbog biološkog nestanka svedoka, a time je znatno otežana pokrenuta revizija popisa. Koristeći se raznovrsnom arhivskom građom, literaturom i anketnim formularima, SZS je, uz asistenciju Muzeja žrtava genocida, otpočeo 1995. godine rad na reviziji popisa, identifikaciji novih osoba i proveri postojećih podataka u popisu njihovim ukrštanjem sa podacima iz drugih izvora. Ideja je da se revizijom obuhvate sva lica koja su živela na prostoru Jugoslavije bez obzira na nacionalnu, versku, etničku, političku i vojnu pripadnost čime se ispravlja osnovna metodološka greška nepopisivanja „kolaboracionista”. Ispravka je usmerena i na utvrđivanje počinilaca zločina odnosno odgovornih za stradanje što nije činjeno 1964. godine (iako su popisnice pune podataka o izvršiocima zločina), na utvrđivanje broja Roma koji nisu posebno popisivani već su vođeni uglavnom kao ostale ili nepoznate nacionalnosti ili pak, kao što je bio slučaj na teritoriji NDH, kao Hrvati, a u manjem broju kao Srbi ili Muslimani, zatim na otklanjanje netačnosti u podacima, što sve dovodi do promenjivosti podataka. Stoga izložene podatke vezane za ove kategorije treba primiti sa rezervom. Revizija je u SZS sa prekidima obavljana do 1999. godine, a od 2003. sprovodi se u MZG, u skladu sa kadrovskim, materijalnim i tehničkim mogućnostima Muzeja. Do sada je revizijom za područje Jugoslavije utvrđen broj od 657.290 stradalih što je povećanje od 10,04\% (59.967 osoba). Arhiv Jugoslavije (AJ), fond 179, popis Žrtve rata 1941-1945; Arhiv Muzeja žrtava genocida (AMŽG), fond Žrtve rata 1941-1945. godine. Opširnije o popisu „Žrtve rata“ videti: Dragan Cvetković, „Gubici pripadnika partizanskog pokreta sa teritorije Jugoslavije 1941-1945“ (doktorska disertacija, Univerzitet u Beogradu, Filozofski fakultet, Odeljenje za istoriju, 2016), 6-10.

${ }^{6}$ Poimenični popisi ljudskih gubitaka Drugog svetskog rata i posleratnog perioda nastali su kako korišćenjem dokumenata tako i na osnovu svedočenja preživelih (rodbine, prijatelja i dr.). Time se otvara pitanje pouzdanosti dobijenih podataka, pa im treba prilaziti kritički kada su u pitanju okolnosti, vreme i mesto stradanja, kao i tvrdnje o učiniocu zločina. Jedan od zadataka revizije 
kojima raspolaže, vrlo indikativan, jer otvara mogućnost njihove analize na vrlo reprezentativnom uzorku. Dosadašnje iskustvo sa prezentacijom dostignutih rezultata revizije popisa pokazuje da su oni uglavnom pogrešno (ili možda namerno) smatrani konačnim, te su kao takvi predstavljani u istoriografskoj literaturi i medijima. Na osnovu dostignutih rezultata u reviziji popisa, njegove obuhvatnosti, napravljena je procena broja stradalih, te su sve analize urađene na osnovu proračunatog broja stradalih. ${ }^{7} \mathrm{U}$ radu je komparativno analizirana teritorijalna pripadnost u Jasenovcu stradalih civila sa teritorije NDH, sagledana je uloga logora u uništavanju civila iz različitih delova NDH, te su naglašene razlike u njihovom stradanju u zavisnosti od demografskog potencijala teritorije sa koje su poticali. S obzirom na heterogenu nacionalnu strukturu ukupne teritorije i njenih regiona, sagledana je nacionalna struktura stradalih u Jasenovcu, iskazane su razlike u pretrpljenim gubicima u logoru, kako među različitim nacionalnostima sa iste teritorije (regiona), tako i razlike u gubicima u okviru istog naroda iz različitih delova NDH, te je sagledana njegova uloga u uništavanju različitih nacionalnosti sa ukupno posmatrane teritorije, kao i njenih delova. ${ }^{8}$

Vojni slom Kraljevine Jugoslavije u kratkotrajnom Aprilskom ratu doveo je do dezintegracije države koja je podeljena na osam delova, različitih veličina i demografskog potencijala, sa različitim pravnim statusima. Teritorija koju je dobila novooformljena NDH je prema popisu iz 1931. godine imala 5.559.420 stanovnika, što je bilo 39,90\% populacije tadašnje Jugoslavije. ${ }^{9}$ Stanovništvo je živelo u 12 geografskih regiona ${ }^{10}$ nejednakog demografskog potencijala. Najveći region je bio Severozapadna Hrvatska u kojoj je živela petina

popisa jeste provera tih podataka ukrštanjem sa saznanjima iz drugih izvora, a zatim njihova verifikacija ili odbacivanje.

${ }^{7}$ Svi odnosi među posmatranim parametrima izraženi u procentima (\%) predstavljaju njihov realan odnos u revidiranom popisu i na osnovu njih su rađeni proračuni. Mogućnost greške pri računanju je $\pm 0,15 \%$ i posledica je prihvaćenih okruglih brojeva ukupnih gubitaka u Jugoslaviji, odnosno NDH, koji su poslužili kao polazna osnova proračuna, te korišćenja celih brojeva, pošto se radi o stradalim osobama, kao i ukrštanja podataka.

${ }^{8}$ Stradanje civila iz različitih delova NDH u Jasenovcu i van njega uticalo je na istorijsko sećanje o pretrpljenim gubicima ljudi iz tih regiona. Utvrđivanje udela Jasenovca u gubicima ljudi iz različitih delova NDH važno je za istraživanje sećanja, kao i promena koje su vremenom nastale u kolektivnoj svesti o stradanju kao posledice njegovog zanemarivanja, neobaveštenosti, ali i različitih konstrukcija i manipulacija.

${ }^{9}$ Proračun za brojnost stanovništva NDH urađen je na osnovu popisa stanovništva iz 1931. godine (Definitivni rezultati popisa stanovništva od 31.3.1931.godine knjiga I; Prisutno stanovništvo, broj kuća i domaćinstava, Beograd: Državna štamparija, 1937). Prema Brojitbenom izveštaju iz 1942. godine teritorija je na osnovu popisa iz 1931. godine imala 5.657.085 stanovnika, ali su u njega uključene i neke teritorije koje su pripadale Mađarskoj i Italiji. Fikreta Jelić-Butić, Ustaše $i$ NDH (Zagreb: SN Liber - Školska knjiga, 1977), 105-106.

${ }^{10}$ Regione treba posmatrati isključivo kao geografske celine pošto oni u tom periodu nisu postojali kao administrativne jedinice i nastali su iz potrebe da se u radu lakše sagleda stradanje civila. Regioni su obuhvatali opštine ili njihove delove prema administrativnoj podeli iz 1964. godine. 
populacije države (19,57\%), u Slavoniji 14,35\%, na Baniji 3,20\%, Kordunu 3,37\%, Lici 3,14\%, delovima Gorskog kotara sa hrvatskim primorjem i Dalmacije 2,38\% odnosno 6,50\%, Bosanskoj Krajini 11,76\%, Srednjoj Bosni 8,97\%, Istočnoj Bosni 15,57\%, Hercegovini 5,50\% i Sremu 5,69\%. ${ }^{11}$ Nacionalna struktura stanovništva ${ }^{12}$ koje se našlo u novoformiranoj državi bila je izuzetno heterogena, a činilo ju je 47,58\% Hrvata, 13,00\% Muslimana (koji su tretirani kao Hrvati druge vere), 32,02\% Srba, 2,63\% Nemaca, 1,23\% Mađara, 0,66\% Slovenaca, $0,57 \%$ Jevreja i $2,31 \%$ ostalih i nepoznatih nacionalnosti, ${ }^{13}$ u koje su uračunati i Romi (oko 0,50\% populacije). ${ }^{14}$ Hrvati su činili apsolutnu većinu u 5 regiona, Severozapadnoj Hrvatskoj, Kordunu, Gorskom kotaru sa hrvatskim primorjem, delu Dalmacije i Slavoniji, ${ }^{15}$ imali su relativnu većinu u Hercegovini

${ }^{11}$ Severozapadna Hrvatska 1.087.946, Banija 178.163, Kordun 187.599, Lika 174.370, Gorski kotar sa hrvatskim primorjem 132.481, deo Dalmacije 361.285, Slavonija 797.577, Bosanska Krajina 654.038, Srednja Bosna 498.469, Istočna Bosna 865.418, Hercegovina 305.630 i Srem 316.444.

${ }^{12}$ Izračunavanje nacionalnosti je urađeno na osnovu istog popisa (Definitivni rezultati popisa stanovništva od 31. marta 1931. godine, knjiga II, Prisutno stanovništvo prema veroispovesti (Beograd: Državna štamparija, 1938), zatim publikacija: Demografska statistika, Stanovnišstvo predratne Jugoslavije po veroispovesti i maternjem jeziku po popisu od 31-III-1931. god., pregled po srezovima (Beograd: Državni statistički ured Demokratske Federativne Jugoslavije, 1945); Demografska statistika, Stanovništvo po veroispovesti i maternjem jeziku po popisu od 31-III-1931. god., Hrvatska, pregled po opštinama (Beograd: Državni statistički ured Demokratske Federativne Jugoslavije, 1945); Демографска статистика, Становништво по вероисповети и матерњем језику по попису од 31-III-1931 године, Босна и Хериеговина, Преглед по општинама (Београд: Државни статистички уред Демократске Федеративне Југославије, 1945); Демографска статистика, Становништво по вероисповести и матерњем језику по попису од 31-III-1931 године, Србија са Војводином и Косово - Метохијом, Преглед по општинама (Београд: Државни статистички уред Демократске Федеративне Југославије, 1945); Bogoljub Kočović, Žrtve Drugog svetskog rata u Jugoslaviji (London: Naše delo, 1985); Vladimir Žerjavić, Gubici stanovništva Jugoslavije u Drugom svjetskom ratu (Zagreb: Jugoslavensko viktimološko društvo, 1989).

${ }^{13} \mathrm{Na}$ teritoriji na kojoj je kasnije formirana NDH prema popisu stanovništva 1931. godine živelo je 2.644.462 Hrvata, 1.780.457 Srba, 722.663 Muslimana, 31.469 Jevreja, 146.019 Nemaca, 68.628 Mađara, 37.000 Slovenaca i 128.724 ostalih i nepoznatih nacionalnosti. Prema proceni nemačkog ministarstva spoljnih poslova iz maja 1941. u NDH je živelo 6.285.000 stanovnika među kojima je bilo 52,51\% Hrvata (3.300.000), 30,63\% Srba (1.925.000), 11,14\% Muslimana (700.000), $2,39 \%$ Nemaca (150.000), 1,19\% Mađara (75.000), 0,59\%, 0,48\% Slovenaca (30.000), 1,03\% Čeha i Slovaka (65.000) i 0,64\% Jevreja (40.000). Autori iz NDH su proračunali populaciju od 6.439.331 stanovnika od kojih je 4.868.831 Hrvat, 1.250.000 Srba, 170.500 Nemaca, 69.000 Mađara, 37.000 Slovenaca, 44.000 Čeha i Slovaka. F. Jelić-Butić, Ustaše i NDH, 106.

${ }^{14}$ Kao osnova za proračune u daljem radu uzet je aproksimativni broj od 30.000 Roma u NDH. Demografska istraživanja na osnovu popisa jezičke pripadnosti pokazala su da je na toj teritoriji živelo oko 21.000 Roma, mada je svakako postojao deo koji se nije izjasnio ili je pak bio dovoljno asimilovan da je govorio drugim jezikom (većim delom hrvatskim i manjim srpskim, što otvara pitanje njihovog nacionalnog identiteta), te su se i neretko tako i nacionalno opredeljivali. (B. Kočović, Žrtve...., 173-176; V. Žerjavić, Gubici...., 36-45). Dosadašnji rezultati u broju identifikovanih Roma tokom revizije popisa, aktuelna obuhvaćenost potencijalnih žrtava i nesrazmerno veliki udeo dece do 14 godina starosti među identifikovanima, pokazuju da je ukupan broj stradalih Roma veći od broja koji su demografi procenili kao ukupan broj Roma ove teritorije.

15 Severozapadna Hrvatska: 89,13\% Hrvata (969.747), 4,06\% Srba (44.134), 2,76\% Slovenaca (30.000), 0,17\% Muslimana (1.828), 1,01\% Jevreja (11.039), 0,81\% Nemaca (8.798), 0,79\% Mađara (8.578), 1,27\% ostalih i nepoznatih (13.822); Kordun: 52,97\% Hrvata (99.369), 
i Srednjoj Bosni, ${ }^{16}$ u kojima su zajedno sa Muslimanima činili većinski deo populacije, dok su Muslimani imali relativnu većinu u Istočnoj Bosni, u kojoj su činili većinu zajedno sa Hrvatima. ${ }^{17} \mathrm{U}$ četiri regiona, Baniji, Lici, Bosanskoj Krajini i Sremu, Srbi su bili većinski deo stanovništva, ${ }^{18}$ dok su na Kordunu činili manje od polovine populacije, u Istočnoj Bosni dve petine, a u Srednjoj Bosni i Hercegovini po trećinu. Od svih Srba u NDH 22,97\% je živelo u Bosanskoj Krajini, 19,56\% u Istočnoj Bosni, 10,46\% Slavoniji, 10,34\% Sremu, 9,14\% Srednjoj Bosni, 5,51\% u Hercegovini, 5,42\% Lici, 5,17\% na Baniji, 4,81\% Kordunu, 2,67\% u delu Dalmacije, 2,48\% Severozapadnoj Hrvatskoj i 1,46\% u delu Gorskog kotara sa hrvatskim primorjem. Više od polovine Hrvata NDH živelo je u Severozapadnoj Hrvatskoj i Slavoniji, 36,67\% odnosno 16,64\%, sa $11,74 \%$ u delu Dalmacije, 6,97\% Srednjoj Bosni, 5,18\% Hercegovini, 4,85\% Istočnoj Bosni, 3,99\% Gorskom kotaru sa hrvatskim primorjem, 3,76\% na Kordunu, 3,15\% Baniji, 2,93\% u Lici, 2,64\% Bosanskoj Krajini i 1,47\% u Sremu. Muslimani su bili koncentrisani u BiH, tako da ih je polovina živela u Istočnoj Bosni (50,02\%), zatim 21,83\% odnosno 17,82\% u Bosanskoj Krajini i Srednjoj Bosni i 9,68\% u Hercegovini, dok je ostalih $0,65 \%$ živelo u ostalim regionima NDH. Vezani za urbane centre, Jevreji iz NDH su najvećim delom bili koncentrisani u tri oblasti, tako da ih je trećina živela u Severozapadnoj Hrvatskoj $(35,04 \%)$, više od četvrtine u Istočnoj Bosni $(28,75 \%)$ i petina u Slavoniji $(21,83 \%)$, dok ih je od ostalih 4,38\% živelo u Sremu, 3,80\% u Srednjoj Bosni, 2,39\% u Bosanskoj Krajini i 3,89\% u ostalih šest regiona. Najveći deo Roma je bio koncentrisan u ravničarskim krajevima uz reku Savu, sa većinom koja je živela u Slavoniji, Sremu i Severozapadnoj Hrvatskoj.

Svi antagonizmi, sve suprotnosti i podele, nacionalne, političke, ideološke, verske, kulturne, ekonomske, koje su postojale u predratnom društvu na ovoj teritoriji, kao i u njenim regionima, u ratu su dobile svoje ekstremne vred-

45,66\% Srba (85.660), 0,10\% Muslimana (191), 1,07\% Jevreja (2.013); Gorski kotar sa hrvatskim primorjem: $79,66 \%$ Hrvata (105.540), 19,65\% Srba (26.031), 0,01\% Muslimana (17), $0,07 \%$ Jevreja (92), 0,61\% ostalih i nepoznatih (801); deo Dalmacije: $85,95 \%$ Hrvata (310.546), 13,14\% Srba (47.468), 0,13\% Muslimana (457), 0,04\% Jevreja (158), 0,73\% ostalih i nepoznatih (2.656); Slavonija: 55,18\% Hrvata (440.084), 23,36\% Srba (186.334), 0,88\% Slovenaca (7.000), 0,17\% Muslimana (1.358), 0,86\% Jevreja (6.878), 8,99\% Nemaca (71.683), $5,55 \%$ Mađara (44.268), 5,01\% ostalih i nepoznatih (39.972).

${ }^{16}$ Hercegovina: 44,87\% Hrvata (137.140), 32,13\% Srba (98.192), 22,90\% Muslimana (70.001), 0,05\% Jevreja (162), 0,04\% ostalih i nepoznatih (135); Srednja Bosna: 36,99\% Hrvata (184.396), 32,66\% Srba (162.819), 25,83\% Muslimana (128.754), 0,24\% Jevreja (1.196), $4,27 \%$ ostalih i nepoznatih (21.304).

17 Istočna Bosna: 41,77\% Muslimana (361.527), 40,24\% Srba (348.224), 14,81\% Hrvata (128.176), 1,05\% Jevreja (9.054), 2,13\% ostalih i nepoznatih (18.437).

${ }^{18}$ Banija: 51,67\% Srba (92.060), 46,79\% Hrvata (83.372), 0,13\% Muslimana (241), 0,22\% Jevreja (391), 1,18\% ostalih i nepoznatih (2.099); Lika: 55,32\% Srba (96.468), 44,43\% Hrvata (77.470), 0,05\% Muslimana (81), Jevreja (1), 0,20\% ostalih (350); Bosanska Krajina: $62,52 \%$ Srba (408.906), 10,66\% Hrvata (69.751), 24,13\% Muslimana (157.797), 0,11\% Jevreja (753), 2,57\% ostalih i nepoznatih (16.831); Srem: 58,20\% Srba (184.161), 12,28\% Hrvata (38.871), $0,13 \%$ Muslimana (411), 0,43\% Jevreja (1.379), 15,59\% Nemaca (49.345), 3,64\% Mađara (11.537), 3,82\% Slovaka (12.096), 5,89\% ostalih i nepoznatih (18.644). 
nosti i u većoj ili manjoj meri su učestvovale u kreiranju uslova za masovno stradanje stanovništva, uz neosporan uticaj koji je spoljni faktor (Nemačka i Italija) permanentno ostvarivao na terenu.

U izrazito kompleksnom i slojevitom ratu vođenom na teritoriji NDH, u kome je učešće imalo više zaraćenih strana (domaćih i inostranih), različitih političkih, ideoloških, nacionalnih, verskih, ekonomskih težnji i aspiracija, stradanje civilnog stanovništva je bilo vrlo izraženo. Stradali civili sa teritorije NDH (između 499.000 i 530.000) predstavljali su 73,39\% ukupnih gubitaka civila Jugoslavije. ${ }^{19}$

Sprovođenje genocida i holokausta kao njegovog najekstremnijeg oblika nad delom stanovništva od strane ustaškog režima i nemačkih okupatora, te masovno činjenje ratnih zločina od strane većine učesnika rata, dovelo je do nesrazmernog stradanja civila različitih nacionalnosti. Među stradalim civilima NDH bilo je 66,48\% Srba (331.735 do 352.344), 10,20\% Hrvata (50.898 do 54.060), 7,77\% Muslimana (38.772 do 41.181), 5,83\% Jevreja (29.092 do $30.899), 4,86 \%$ Roma (24.251 do 25.758$), 1,26 \%$ ostalih nacionalnosti (6.287 do 6.678) i 3,60\% neutvrđenih ${ }^{20}$ nacionalnosti (17.964 do 19.080). Pretrpljeni gubici različitih nacionalnosti nisu bili u skladu sa njihovom zastupljenošću u populaciji NDH.

Tabela 1. NDH, civili - učešće u populaciji i učešće u gubicima civila prema nacionalnoj pripadnosti

\begin{tabular}{|c|c|c|}
\hline $\begin{array}{l}\text { NDH, civili } \\
\text { nacionalnosti }\end{array}$ & $\begin{array}{c}\text { \% učešće } \\
\text { u populaciji NDH }\end{array}$ & $\begin{array}{c}\% \text { među stradalim } \\
\text { civilima }\end{array}$ \\
\hline Hrvati & 47,58 & 10,20 \\
\hline Srbi & 32,02 & 66,48 \\
\hline Muslimani & 13,00 & 7,77 \\
\hline Jevreji & 0,57 & 5,83 \\
\hline Romi & 0,50 & 4,86 \\
\hline ostali/nepoznati & 6,33 & 4,86 \\
\hline
\end{tabular}

Popis stanovništva 1931. godine, AMŽG, Baza podataka „Žrtve rata 1941-1945“

Proglašeni za nepoželjan element u novoformiranoj državi, izloženi pogromu od prvog dana rata, Srbi su činili dve trećine gubitaka civilnog stanovništva, što je bilo dvostruko više (2,07 puta) od njihove zastupljenosti u populaciji NDH. Na osnovu rasnih zakona uništavani u totalu, Jevreji i Romi

${ }^{19} \mathrm{Na}$ osnovu dostignutih rezultata delimično revidiranog popisa „Žrtve rata $1941-1945 “$ proračunat broj stradalih civila sa teritorije Kraljevine Jugoslavije kreće se između 684.000-718.000. Dragan Cvetković, „Stradanje stanovništva NDH u logorima - numeričko određenje“ u: Logori, zatvori i prisilni rad u Hrvatskoj / Jugoslaviji 1941-1945, 1945-1951, urednik Vladimir Geiger i drugi (Zagreb: HIP, 2010), 45.

${ }^{20}$ Preliminarne analize koje su rađene za grupu „neutvrđene nacionalnosti“ pokazuju da je među njima najviše Roma i Srba, ali za sada ne postoje validni izvori koji potvrđuju ove pretpostavke. 
predstavljaju najveće žrtve rata i njihovi gubici su bili 10,23 odnosno 9,72 puta veći od zastupljenosti u stanovništvu. S druge strane, civilni gubici hrvatskog i muslimanskog naroda su bili 4,66 odnosno 1,67 puta manji od učešća ovih nacionalnih grupa u populaciji NDH. S obzirom na zastupljenost u populaciji, gubici civilnog stanovništva srpske nacionalnosti u NDH realno su bili 9,64 puta brojniji od hrvatskih i 3,48 puta od muslimanskih civilnih gubitaka, dok su gubici muslimanskih civila bili 2,79 puta veći od hrvatskih. Uništeni u holokaustu gubici Jevreja i Roma su bili realno višestruko veći od stradanja svih ostalih nacionalnosti. $^{21}$

Logor Jasenovac, odnosno sistem logora, predstavljao je najveći koncentracioni logor u Jugoistočnoj Evropi i prema gubicima, svakako, najveći logor u Evropi koji nije organizovala nacistička Nemačka. U njemu je život izgubila četvrtina svih stradalih civila NDH. Obim izvršenog zločina u logoru Jasenovac jasno ga je odredio kao logor uništenja.

Tabela 2. NDH, civili - udeo Jasenovca u ukupnim gubicima

\begin{tabular}{|l|r|r|r|r|c|}
\hline NDH, civili & Ukupno & $\begin{array}{c}\text { Stradali u } \\
\text { Jasenovcu }\end{array}$ & $\%$ & $\begin{array}{c}\text { Na drugim } \\
\text { mestima }\end{array}$ & $\%$ \\
\hline Ukupno & $499.000-$ & $122.279-$ & 24,53 & $376.721-$ & 75,47 \\
& 530.000 & 130.120 & & 399.880 & \\
\hline
\end{tabular}

Proračun na osnovu baze podataka „Žrtve rata 1941-1945“

Stradali u Jasenovcu dovođeni su u logor iz svih delova NDH. Na broj logoraša, a samim time i potencijalnih žrtava - pored stalno prisutne namere vlasti NDH da se izvrši zločin nad delom stanovništva i ratnih dešavanja na tim prostorima - uticalo je više činilaca, od udaljenosti logora i geografskih karakteristika terena $\mathrm{u}$ regionima i njihove demografske strukture, preko postojanja saobraćajnih komunikacija (prvenstveno železničkih) i njihove prohodnosti (odnosno sposobnosti vlasti da održi saobraćaj na njima), dostupnosti potencijalnih žrtava, odnosno sposobnosti ili mogućnosti naroda da se organizuje i zaštiti od terora i masovnog odvođenja u logore, a što je bilo u direktnoj vezi sa sposobnošću NDH da, samostalno ili u saradnji sa Nemcima, ostvari trajnu ili privremenu efektivnu kontrolu terena. Najveći deo stradalih je poticao iz dva regiona sa kojima se logor graničio, trećina iz Slavonije i četvrtina iz Bosanske Krajine, uz osminu gubitaka koji su poticali iz Istočne Bosne. Iz šest od 12 regiona NDH poticalo je 90,94\% gubitaka pretrpljenih u Jasenovcu, dok su gubici iz četiri regiona zbirno predstavljali minimalan deo žrtava logora $(1,89 \%)$.

${ }^{21}$ Opširnije u: Dragan Cvetković, „Holokaust u NDH - numeričko određenje“, Istorija 20. veka, XXIX, br. 1, (2011), 163-182. 
Tabela 3. NDH, civili - učešće u populaciji i učešće u gubicima u Jasenovcu prema nacionalnoj pripadnosti

\begin{tabular}{|l|r|r|}
\hline $\begin{array}{l}\text { Nezavisna Država } \\
\text { Hrvatska }\end{array}$ & $\begin{array}{c}\text { \% učešće } \\
\text { u populaciji } \\
\text { NDH }\end{array}$ & $\begin{array}{c}\text { \% među } \\
\text { stradalim } \\
\text { u Jasenovcu }\end{array}$ \\
\hline Severozapadna Hrvatska & 19,57 & 8,61 \\
\hline Slavonija & 14,35 & 30,60 \\
\hline Banija & 3,20 & 7,22 \\
\hline Kordun & 3,37 & 3,60 \\
\hline Lika & 3,14 & 0,28 \\
\hline deo Gorskog kotara sa & 2,38 & 0,48 \\
hrvatskim primorjem & 6,50 & 0,34 \\
\hline deo Dalmacije & 11,76 & 25,13 \\
\hline Bosanska Krajina & 8,97 & 3,57 \\
\hline Srednja Bosna & 15,57 & 12,62 \\
\hline Istočna Bosna & 5,50 & 0,79 \\
\hline Hercegovina & 5,69 & 6,76 \\
\hline Srem & &
\end{tabular}

Popis stanovništva 1931. i proračun na osnovu baze podataka „Žrtve rata 1941-1945“

Pretrpljeni gubici u logoru žrtava iz različitih delova NDH nisu bili u skladu sa zastupljenošću tih regiona u populaciji NDH. Stradali iz 4 regiona su imali veće učešće u gubicima u Jasenovcu nego što im je bila zastupljenost u populaciji NDH, Banija 2,25 puta, Bosanska Krajina 2,14 puta, Slavonija 2,13 puta i Srem sa 1,19 puta većim učešćem. Kordun je predstavljao jedini region NDH koji je imao približno isto učešće u gubicima u logoru sa učešćem u stanovništvu. ${ }^{22}$ Stradali iz ostalih 7 regiona NDH su imali daleko manje učešće u gubicima u Jasenovcu od njihove zastupljenosti u populaciji, deo Dalmacije 19,12 puta, Lika 11,21 puta, Hercegovina 6,96 puta, deo Gorskog kotara sa hrvatskim primorjem 4,96 puta, Srednja Bosna 2,51 puta, Severozapadna Hrvatska 2,27 puta i Istočna Bosna 1,23 puta manje. Time je pretrpljeni gubitak u Jasenovcu logoraša sa Banije, s obzirom na zastupljenost u stanovništvu, bio realno 43,12 odnosno 25,27 puta veći od gubitka logoraša iz dela Dalmacije i Like i 5,14 odnosno 2,78 puta veći od gubitka stradalih iz Severozapadne Hrvatske i Istočne Bosne. ${ }^{23}$

Jasenovac kao mesto stradanja civila nije imao jednaku ulogu u njihovom uništavanju u svim delovima NDH. Više od polovine svih stradalih civila Slavonije izgubilo je život u njemu, kao i dve petine iz Srema, trećina stradalih civila sa Banije, po četvrtina iz Severozapadne Hrvatske i Bosanske Krajine, ali i minimalni delovi stradalih civila dela Dalmacije, Like i Hercegovine. Time je udeo u gubicima stradalih u Jasenovcu među stradalim civilima Slavonije bio 1,65 puta veći od udela u gubicima u logoru civila sa Banije, dvostruko veći nego kod civila

${ }^{22}$ Učešće stradalih civila sa Korduna u gubicima u logoru Jasenovac bilo je stvarno 1,07 puta veće od njihove zastupljenosti u populaciji NDH.

${ }^{23}$ Realni gubitak logoraša sa Banije je bio po 1,06 puta veći od gubitaka logoraša iz Slavonije i Bosanske krajine kao najbrojnijih u gubicima, te 1,90 puta veći od gubitaka logoraša iz Srema. 
Severozapadne Hrvatske i Bosanske Krajine (2,03 odnosno 2,32 puta), 3,11 puta od civila Istočne Bosne, ali i 42,27 puta veći nego kod civila Like.

Tabela 4. NDH, civili - mesto stradanja prema teritorijalnoj pripadnosti

\begin{tabular}{|c|c|c|c|c|c|}
\hline $\begin{array}{l}\mathrm{NDH}- \\
\text { civili }\end{array}$ & Ukupno & $\begin{array}{l}\text { Stradali u } \\
\text { Jasenovcu }\end{array}$ & $\%$ & $\begin{array}{c}\text { Na ostalim } \\
i \\
\text { nepoznatim } \\
\text { mestima }\end{array}$ & $\%$ \\
\hline $\begin{array}{l}\text { Severozapadna } \\
\text { Hrvatska }\end{array}$ & $\begin{array}{r}39.471- \\
41.923 \\
\end{array}$ & $\begin{array}{r}10.528- \\
11.203 \\
\end{array}$ & 26,70 & $\begin{array}{r}28.943- \\
30.720 \\
\end{array}$ & 73,30 \\
\hline$\%$ & 7,91 & 8,61 & $/ /$ & 7,68 & // \\
\hline Slavonija & $\begin{array}{r}69.211- \\
73.511\end{array}$ & $\begin{array}{r}37.417- \\
39.817\end{array}$ & 54,11 & $\begin{array}{r}31.794- \\
33.694\end{array}$ & 45,89 \\
\hline$\%$ & 13,87 & 30,60 & 11 & 8,43 & /1 \\
\hline Banija & $\begin{array}{r}26.996- \\
28.673 \\
\end{array}$ & $\begin{array}{r}8.828- \\
9.395\end{array}$ & 32,73 & $\begin{array}{r}18.168- \\
19.278 \\
\end{array}$ & 67,27 \\
\hline$\%$ & 5,41 & 7,22 & // & 4,82 & // \\
\hline Kordun & $\begin{array}{r}34.032- \\
36.146 \\
\end{array}$ & $\begin{array}{r}4.402- \\
4.684\end{array}$ & 12,94 & $\begin{array}{r}29.630- \\
31.462 \\
\end{array}$ & 87,06 \\
\hline$\%$ & 6,82 & 3,60 & // & 7,87 & // \\
\hline Lika & $\begin{array}{r}26.696- \\
28.355 \\
\end{array}$ & $342-364$ & 1,28 & $\begin{array}{r}26.354- \\
27.991 \\
\end{array}$ & 98,72 \\
\hline$\%$ & 5,35 & 0,28 & /1 & 7,00 & /1 \\
\hline $\begin{array}{l}\text { deo Gorskog } \\
\text { kotara sa } \\
\text { hrvatskim } \\
\text { primorjem }\end{array}$ & $\begin{array}{r}6.537- \\
6.943\end{array}$ & $587-624$ & 8,98 & $\begin{array}{r}5.950- \\
6.319\end{array}$ & 91,02 \\
\hline$\%$ & 1,31 & 0,48 & /1 & 1,58 & // \\
\hline deo Dalmacije & $\begin{array}{r}11.926- \\
12.667 \\
\end{array}$ & $416-442$ & 3,49 & $\begin{array}{r}11.510- \\
12.225 \\
\end{array}$ & 96,51 \\
\hline$\%$ & 2,39 & 0,34 & $1 /$ & 3,06 & $/ /$ \\
\hline $\begin{array}{l}\text { Bosanska } \\
\text { Krajina } \\
\end{array}$ & $\begin{array}{r}132.165- \\
140.397 \\
\end{array}$ & $\begin{array}{r}30.728- \\
32.699 \\
\end{array}$ & 23,27 & $\begin{array}{r}101.457- \\
107.698 \\
\end{array}$ & 76,73 \\
\hline$\%$ & 26,49 & 25,13 & $1 /$ & 26,93 & // \\
\hline Srednja Bosna & $\begin{array}{r}24.052- \\
25.546 \\
\end{array}$ & $\begin{array}{r}4.365- \\
4.645 \\
\end{array}$ & 18,17 & $\begin{array}{r}19.687- \\
20.901 \\
\end{array}$ & 81,83 \\
\hline$\%$ & 4,82 & 3,57 & // & 5,22 & // \\
\hline Istočna Bosna & $\begin{array}{r}88.922- \\
94.446 \\
\end{array}$ & $\begin{array}{r}15.432- \\
16.421 \\
\end{array}$ & 17,37 & $\begin{array}{r}73.490- \\
78.025 \\
\end{array}$ & 82,63 \\
\hline$\%$ & 17,82 & 12,62 & 11 & 19,51 & // \\
\hline Hercegovina & $\begin{array}{r}17.365- \\
18.444 \\
\end{array}$ & $966-1.028$ & 5,57 & $\begin{array}{r}16.399- \\
17.416 \\
\end{array}$ & 94,43 \\
\hline$\%$ & 3,48 & 0,79 & $1 /$ & 4,35 & $1 /$ \\
\hline Srem & $\begin{array}{r}21.607- \\
22.949 \\
\end{array}$ & $\begin{array}{r}8.266- \\
8.796 \\
\end{array}$ & 38,30 & $\begin{array}{r}13.341- \\
14.153 \\
\end{array}$ & 61,70 \\
\hline$\%$ & 4,33 & 6,76 & // & 3,54 & // \\
\hline Ukupno & $\begin{array}{r}499.000- \\
530.000\end{array}$ & $\begin{array}{r}122.279- \\
130.120\end{array}$ & 24,53 & $\begin{array}{r}376.721- \\
399.880\end{array}$ & 75,47 \\
\hline
\end{tabular}

Proračun na osnovu baze podataka „Žrtve rata 1941-1945“ 
Pretrpljeni gubici civila iz različitih delova NDH nisu imali istu zastupljenost $\mathrm{u}$ gubicima prema njihovom mestu stradanja. Kod stradalih civila tri regiona učešće u pretrpljenim gubicima u Jasenovcu je bilo veće od zastupljenosti u gubicima na drugim mestima, Slavoniji 3,63 puta, Sremu 1,91 i Baniji 1,50 puta. Severozapadna Hrvatska i Bosanska Krajina su imale približno istu zastupljenost u gubicima u Jasenovcu i na ostalim i nepoznatim mestima. U ostalih sedam regiona učešće u gubicima u Jasenovcu je bilo manje od učešća u gubicima na drugim mestima, Lici 25,00 puta, delu Dalmacije 9,00 puta, Hercegovini 5,51 puta, delu Gorskog kotara sa hrvatskim primorjem 3,29 puta, Kordunu 2,19 puta, Istočnoj Bosni 1,54 puta i Srednjoj Bosni 1,46 puta manje.

Svrha formiranja koncentracionog logora, odnosno sistema logora, kao institucionalnog oblika za eliminaciju pojedinih naroda iz stanovništva NDH, delom ili u celini, kao i za obračun sa političkim i ideološkim protivnicima $\mathrm{NDH}$, odredila je nacionalnu strukturu gubitaka u Jasenovcu. Tri petine ukupnih gubitaka u Jasenovcu predstavljali su Srbi, šestinu Romi, sedminu Jevreji, dvadeseti deo Hrvati, uz minimalno učešće u gubicima Muslimana i pripadnika ostalih i nepoznatih nacionalnosti. Nominalno gubitak koji su Srbi pretrpeli u logoru bio je 4,30 odnosno 4,07 puta veći od gubitka Jevreja i Roma i 12,83 odnosno 56,74 puta veći od gubitka Hrvata i Muslimana, gubitak Jevreja i Roma je bio 2,98 odnosno 3,15 puta veći od gubitka Hrvata i 13,21 odnosno 13,96 puta od gubitaka Muslimana, dok je pretrpljeni gubitak Hrvata bio 4,42 puta veći od gubitka Muslimana.

Tabela 5. Logor Jasenovac - nacionalna struktura gubitaka

\begin{tabular}{|c|c|c|c|c|c|c|c|c|c|c|c|c|c|}
\hline $\begin{array}{l}\mathrm{NDH}- \\
\text { Jasenovac }\end{array}$ & Ukupno & Srbi & $\%$ & Jevreji & $\%$ & Romi & $\%$ & Hrvati & $\%$ & Muslim. & $\%$ & $\begin{array}{c}\text { Ostali i } \\
\text { nepoznati }\end{array}$ & $\%$ \\
\hline \begin{tabular}{|l|} 
Ukupno \\
\end{tabular} & $\begin{array}{c}122.279 \\
130.120\end{array}$ & $\begin{array}{l}77.011- \\
81.950 \\
\end{array}$ & 62,98 & $\begin{array}{c}17.926- \\
19.076 \\
\end{array}$ & 14,66 & $\begin{array}{c}18.916- \\
20.129 \\
\end{array}$ & 15,47 & \begin{tabular}{|c|}
$6.004-$ \\
6.389 \\
\end{tabular} & 4,91 & $\begin{array}{c}1.357- \\
1.444 \\
\end{array}$ & 1,11 & $\begin{array}{c}1.064- \\
1.132 \\
\end{array}$ & 0,87 \\
\hline
\end{tabular}

Proračun na osnovu baze podataka „Žrtve rata 1941-1945“6

Unapred utvrđena namera ustaškog pokreta da se određeni narodi u NDH unište u potpunosti ili značajnim delom bila je najuočljivija na primeru logora Jasenovac. Takva težnja je uslovila da nacionalna struktura stradalih u Jasenovcu nije bila u skladu sa zastupljenošću nacionalnosti u stanovništvu, te im ni realni gubici nisu bili jednaki. Jevreji i Romi su predstavljali najveće žrtve logora $\mathrm{s}$ obzirom na to da je njihovo učešće u gubicima u logoru bilo 25,72 odnosno 30,94 puta veće od njihovog učešća u populaciji NDH. Takođe je i zastupljenost Srba u gubicima logora bila dvostruko veća (1,97 puta) od njihovog učešća u stanovništvu NDH. S druge strane, učešće Hrvata i Muslimana među stradalima u logoru Jasenovac bilo je 9,69 odnosno 11,71 puta manje od njihove zastupljenosti u populaciji. Time je gubitak koji su pretrpeli 
Jevreji i Romi ${ }^{24}$ realno bio 13,09 odnosno 15,73 puta veći od gubitka Srba, 248,75 odnosno 299,75 puta veći od gubitka Hrvata i 301,96 odnosno 392,96 puta veći od gubitka Muslimana. Kao najbrojniji među stradalima u logoru, Srbi su pretrpeli gubitke koji su realno bili 18,99 odnosno 23,06 puta veći od gubitaka Hrvata i Muslimana, dok je pretrpljeni gubitak Hrvata realno bio 1,21 puta veći od gubitka Muslimana.

Uloga logora Jasenovac u uništenju pojedinih nacionalnosti nije bila jednaka, a razlike su postojale kako u udelu stradalih u logoru u ukupnim gubicima pojedinih nacionalnosti, tako i u odnosu učešća pojedinih nacionalnosti u gubicima u logoru prema ukupnim gubicima civila iste nacionalnosti, a takođe $\mathrm{i}$ u odnosu na gubitke pretrpljene na drugim mestima.

Tabela 6. NDH, civili - uloga Jasenovca u uništavanju civila prema nacionalnoj pripadnosti

\begin{tabular}{|c|c|c|c|c|c|}
\hline NDH, civili & Ukupno & $\begin{array}{l}\text { Stradali u } \\
\text { Jasenovcu }\end{array}$ & $\%$ & $\begin{array}{c}\mathrm{Na} \\
\text { drugim } \\
\text { mestima }\end{array}$ & $\%$ \\
\hline Srbi & $\begin{array}{r}331.735- \\
352.344\end{array}$ & $\begin{array}{r}77.011- \\
81.950\end{array}$ & 23,24 & $\begin{array}{r}254.724 \\
270.394\end{array}$ & 76,75 \\
\hline$\%$ & 66,48 & 62,98 & $1 /$ & 67,62 & /1 \\
\hline Hrvati & $\begin{array}{r}50.898- \\
54.060\end{array}$ & $\begin{array}{r}6004- \\
6.389\end{array}$ & 11,81 & $\begin{array}{r}44.894 \\
47.671\end{array}$ & 88,19 \\
\hline$\%$ & 10,20 & 4,91 & /I & 11,92 & /I \\
\hline Muslimani & $\begin{array}{r}38.772- \\
41.181\end{array}$ & $\begin{array}{r}1.357- \\
1.444\end{array}$ & 3,50 & $\begin{array}{r}37.415- \\
39.737\end{array}$ & 96,50 \\
\hline$\%$ & 7,77 & 1,11 & $/ /$ & 9,93 & // \\
\hline Jevreji & $\begin{array}{r}29.092- \\
30.899\end{array}$ & $\begin{array}{r}17.926- \\
19.076\end{array}$ & 61,68 & $\begin{array}{r}11.166- \\
11.823\end{array}$ & 38,32 \\
\hline$\%$ & 5,83 & 14,66 & // & 2,96 & // \\
\hline Romi & $\begin{array}{r}24.251- \\
25.758\end{array}$ & $\begin{array}{r}18.916- \\
20.129\end{array}$ & 78,08 & $\begin{array}{r}5.335- \\
5.629\end{array}$ & 21,92 \\
\hline$\%$ & 4,86 & 15,47 & /1 & 1,42 & // \\
\hline ostali/nepoznati & $\begin{array}{r}24.251- \\
25.758\end{array}$ & $\begin{array}{r}1.064 \\
1.132\end{array}$ & 4,39 & $\begin{array}{r}23.187- \\
24.626\end{array}$ & 95,61 \\
\hline$\%$ & 4,86 & 0,87 & // & 6,15 & $/ /$ \\
\hline ukupno & $\begin{array}{r}499.000- \\
530.000\end{array}$ & $\begin{array}{r}122.279 \\
130.120\end{array}$ & 24,53 & $\begin{array}{r}376.721- \\
399.880\end{array}$ & 75,47 \\
\hline
\end{tabular}

Proračun na osnovu baze podataka „Žrtve rata 1941-1945“

Za Jevreje i Rome, koji su rasnim zakonima unapred bili određeni za uništenje, Jasenovac je predstavljao centralno mesto stradanja. U njemu je život izgubilo četiri petine stradalih Roma, odnosno tri petine stradalih Jevreja NDH. Masovni teror sprovođen nad srpskim narodom u NDH imao je sve odlike zločina genocida, bilo da se sprovodio institucionalno u logorima i zatvorima, ili da

\footnotetext{
${ }^{24} \mathrm{~S}$ obzirom na zastupljenost u populaciji NDH, pretrpljeni gubitak Roma u Jasenovcu je bio realno za petinu veći (1,20 puta) od gubitka Jevreja.
} 
se radilo o masovnim ili pojedinačnim zločinima širom te teritorije. Jasenovac je imao istaknuto mesto u sprovođenju tog zločina, pošto je u njemu život izgubila četvrtina od svih stradalih civila srpske nacionalnosti iz NDH, čime je on postao primarno mesto njihovog stradanja. U Jasenovcu je život izgubila osmina stradalih civila hrvatske nacionalnosti, trideseti deo civila muslimanske nacionalnosti, te dvadeset treći deo stradalih pripadnika ostalih i nepoznatih nacionalnosti. Udeo Jevreja i Roma stradalih u Jasenovcu u ukupnim gubicima ovih nacionalnosti bio je 2,65 odnosno 3,36 puta veći od udela Srba, 5,22 odnosno 6,61 puta veći od udela Hrvata i 17,62 odnosno 22,31 puta veći od udela Muslimana, udeo u Jasenovcu stradalih Srba bio 1,97 odnosno 6,64 puta veći od udela u gubicima Hrvata i Muslimana, dok je udeo Hrvata bio 3,37 puta veći od udela stradalih Muslimana.

Zastupljenost pojedinih nacionalnosti u gubicima u logoru Jasenovac nije uvek bila u skladu sa učešćem u ukupnim gubicima, kao ni sa zastupljenošću u gubicima na drugim mestima. Najmanje razlike su postojale kod Srba kao naroda najbrojnijeg u gubicima, sa učešćem od po dve trećine ukupno stradalih civila, kao i civila stradalih van Jasenovca, dok im je učešće među stradalima u Jasenovcu (od tri petine gubitaka) bilo neznatno manje (1,05 odnosno 1,07 puta). Kod Jevreja i Roma učešće u gubicima u Jasenovcu bilo je 2,51 odnosno 3,18 puta veće od zastupljenosti u ukupnim gubicima civila NDH i 4,95 odnosno 10,89 puta veće od učešća u gubicima na drugim mestima. S druge strane, kod Hrvata je zastupljenost u jasenovačkim žrtvama bila 2,08 puta manja nego u ukupnim gubicima civila NDH odnosno 2,43 puta manja nego kod civila stradalih na drugim mestima, Muslimana 7,00 odnosno 8,94 puta manja, te pripadnika ostalih i nepoznatih nacionalnosti kod kojih je učešće među stradalima u Jasenovcu bilo 5,58 puta manje nego u ukupnim gubicima i 7,07 puta manje nego u stradanju van Jasenovca. ${ }^{25}$

Drugačija nacionalna struktura regiona NDH, težnja vlasti da u potpunosti uništi Jevreje i Rome, a da Srbima radikalno smanji prisustvo u populaciji, te da se obračuna sa političkim i ideološkim protivnicima, uz različita ratna dešavanja na pojedinim delovima teritorije i napred pobrojana ograničenja u logistici, prouzrokovali su razlike u pretrpljenim gubicima u logoru Jasenovac nacionalnosti iz različitih delova NDH. Iz devet od 12 regiona NDH Srbi su predstavljali najveći deo gubitaka pretrpljenih u logoru, svuda sa natpolovičnom većinom. U dva regiona Jevreji su imali najveći udeo u gubicima pretrpljenim u Jasenovcu (sa trećinom odnosno tri petine stradalih), dok su u jednom regionu Romi činili tri petine gubitaka. Hrvati su u jednom regionu činili trećinu i u dva regiona po četvrtinu stradalih u Jasenovcu, dok su Muslimani u jednom regionu predstavljali devetinu gubitaka pretrpljenih u logoru.

\footnotetext{
${ }^{25}$ Opširnije o ulozi Jasenovca u uništavanju pojedinih nacionalnosti, dinamici pretrpljenih gubitaka: Dragan Cvetković, „Koncentracijski logor Jasenovac i njegova uloga u uništavanju naroda NDH - izračun mogućeg broja žrtava na temelju djelimično revidiranog popisa 1964. godine“, u Jasenovac - Manipulacije, kontroverze ..., 171-219.
} 
Tabela 7. NDH, logor Jasenovac - nacionalna struktura prema teritorijalnoj pripadnosti

\begin{tabular}{|c|c|c|c|c|c|c|c|c|c|c|c|c|c|}
\hline \begin{tabular}{l|}
$\mathrm{NDH}-$ \\
Jasenovac \\
\end{tabular} & Ukupno & Srbi & $\%$ & \begin{tabular}{|l|} 
Jevreji \\
\end{tabular} & $\%$ & Romi & $\%$ & Hrvati & $\%$ & $\begin{array}{l}\text { Mus- } \\
\text { lim. }\end{array}$ & $\%$ & $\begin{array}{l}\text { Ostali i } \\
\text { nepozn. }\end{array}$ & $\%$ \\
\hline $\begin{array}{l}\text { Severo- } \\
\text { zapadna } \\
\text { Hrvatska }\end{array}$ & $\begin{array}{r}10.528- \\
11.203\end{array}$ & $\begin{array}{r}1.656- \\
1.762\end{array}$ & 15,73 & $\begin{array}{r}3.813 \\
4.057\end{array}$ & 36,21 & $\begin{array}{r}1.941- \\
2.065\end{array}$ & 18,43 & $\begin{array}{r}2.757 \\
2.934 \\
\end{array}$ & 26,19 & 16-17 & 0,15 & $\begin{array}{r}345- \\
368\end{array}$ & 3,28 \\
\hline$\%$ & 8,61 & 2,15 & $/ /$ & 21,27 & $/ /$ & 10,26 & $/ /$ & 45,92 & $/ /$ & 1,21 & $\pi / 1$ & 3,42 & $/ /$ \\
\hline Slavonija & $\begin{array}{r}37.417- \\
39.817 \\
\end{array}$ & $\begin{array}{r}20.947 \\
22.290\end{array}$ & 55,98 & $\begin{array}{r}3.340- \\
3.554\end{array}$ & 8,93 & $\begin{array}{r}11.340- \\
12.067\end{array}$ & 30,31 & $\begin{array}{r}1.603- \\
1.706\end{array}$ & 4,28 & $6-7$ & 0,02 & $\begin{array}{r}181- \\
193\end{array}$ & 0,48 \\
\hline$\%$ & 30,60 & 27,20 & $/ /$ & 18,63 & $/ /$ & 59,95 & $/ /$ & 26,70 & $/ /$ & 0,48 & $1 /$ & & $/ 1$ \\
\hline Banija & $\begin{array}{r}8.828 \\
9.395\end{array}$ & $\begin{array}{r}8.109 \\
8.629\end{array}$ & 91,85 & $48-51$ & 0,54 & $\begin{array}{r}147- \\
157\end{array}$ & 1,66 & $\begin{array}{r}511- \\
544\end{array}$ & 5,79 & - & - & $13-14$ & 0,15 \\
\hline$\%$ & 7,22 & 10,53 & $/ /$ & 0,27 & $/ 1$ & 0,78 & $/ /$ & 8,51 & $/ /$ & - & $1 /$ & & // \\
\hline Kordun & $\begin{array}{r}4.402- \\
4.684 \\
\end{array}$ & $\begin{array}{r}2.603- \\
2.770 \\
\end{array}$ & 59,13 & $\begin{array}{r}109 \\
116 \\
\end{array}$ & 2,48 & $\begin{array}{r}1.413- \\
1.504 \\
\end{array}$ & 32,10 & $\begin{array}{r}223 \\
237 \\
\end{array}$ & 5,06 & - & - & 54-57 & 1,23 \\
\hline$\%$ & 3,60 & 3,38 & $/ /$ & 0,61 & $/ /$ & 7,47 & $/ /$ & 3,71 & $/ /$ & - & $1 /$ & & $/ /$ \\
\hline Lika & \begin{tabular}{|r|}
$342-$ \\
364 \\
\end{tabular} & $\begin{array}{r}216- \\
229\end{array}$ & 63,16 & - & - & 2 & 0,58 & $\begin{array}{r}120- \\
128\end{array}$ & 35,09 & - & - & $4-5$ & 1,17 \\
\hline$\%$ & 0,28 & 0,28 & $/ /$ & - & $/ /$ & 0,01 & $/ /$ & 2,00 & $/ /$ & - & $1 / 1$ & & $/ 1$ \\
\hline $\begin{array}{l}\text { deo } \\
\text { Gorskog } \\
\text { kotara sa } \\
\text { hrvatskim } \\
\text { primorjem }\end{array}$ & $\begin{array}{r}587- \\
624\end{array}$ & $\begin{array}{r}115 \\
123\end{array}$ & 19,59 & $5-6$ & 0,85 & $\begin{array}{r}335- \\
356\end{array}$ & 57,07 & $\begin{array}{r}116- \\
124\end{array}$ & 19,76 & - & - & $14-15$ & 2,38 \\
\hline$\%$ & 0,48 & 0,15 & $/ /$ & 0,03 & $/ /$ & 1,77 & $/ / 1$ & 1,94 & $/ / 1$ & - & $1 /$ & & /1 \\
\hline $\begin{array}{l}\text { deo } \\
\text { Dalmacije }\end{array}$ & $416-442$ & $\begin{array}{r}293- \\
311\end{array}$ & 70,43 & $14-15$ & 3,36 & 2 & 0,48 & \begin{tabular}{r|}
$106-$ \\
113
\end{tabular} & 25,48 & - & & 1 & 0,24 \\
\hline$\%$ & 0,34 & 0,38 & $/ 1$ & 0,08 & $/ /$ & 0,01 & $/ /$ & 1,77 & $/ /$ & - & $1 /$ & & /I \\
\hline $\begin{array}{l}\text { Bosanska } \\
\text { Krajina }\end{array}$ & $\begin{array}{r}30.728- \\
32.699\end{array}$ & $\begin{array}{r}28.402- \\
30.223\end{array}$ & 92,43 & $\begin{array}{r}249 \\
265\end{array}$ & 0,81 & $\begin{array}{r}1.097- \\
1.167\end{array}$ & 3,57 & $\begin{array}{r}190- \\
202\end{array}$ & 0,62 & $\begin{array}{r}586- \\
624\end{array}$ & 1,91 & $\begin{array}{r}204- \\
218\end{array}$ & 0,66 \\
\hline$\%$ & 25,13 & 36,88 & $/ /$ & 1,39 & $/ /$ & 5,80 & $/ 1$ & 3,17 & $/ /$ & 43,22 & $1 /$ & & /I \\
\hline $\begin{array}{l}\text { Srednja } \\
\text { Bosna }\end{array}$ & $\begin{array}{r}4.365- \\
4.645\end{array}$ & $\begin{array}{r}3.258 \\
3.466\end{array}$ & 74,64 & $\begin{array}{r}706- \\
752\end{array}$ & 16,17 & $68-72$ & 1,55 & $\begin{array}{r}67- \\
71\end{array}$ & 1,53 & $\begin{array}{r}243- \\
259\end{array}$ & 5,57 & $23-25$ & 0,53 \\
\hline$\%$ & 3,57 & 4,23 & $1 /$ & 3,94 & $1 /$ & 0,36 & $/ /$ & 1,11 & $1 /$ & 17,92 & $1 /$ & & /I \\
\hline $\begin{array}{l}\text { Istočna } \\
\text { Bosna }\end{array}$ & $\begin{array}{r}15.432- \\
16.421 \\
\end{array}$ & $\begin{array}{r}6.092- \\
6.482 \\
\end{array}$ & 39,48 & $\begin{array}{r}8.542- \\
9.090 \\
\end{array}$ & 55,35 & $32-34$ & 0,21 & $\begin{array}{r}173- \\
184 \\
\end{array}$ & 1,12 & $\begin{array}{r}393- \\
418 \\
\end{array}$ & 2,55 & $\begin{array}{r}200- \\
213 \\
\end{array}$ & 1,30 \\
\hline$\%$ & 12,62 & 7,91 & $1 /$ & 47,65 & $1 /$ & 0,17 & $/ /$ & 2,88 & $/ /$ & 28,93 & $1 /$ & & /I \\
\hline $\begin{array}{l}\text { Herce- } \\
\text { govina }\end{array}$ & $\begin{array}{c}966- \\
1.028\end{array}$ & \begin{tabular}{r|}
$786-$ \\
836
\end{tabular} & 81,36 & $9-10$ & 0,93 & - & - & $\begin{array}{r}46- \\
49\end{array}$ & 4,76 & $\begin{array}{r}112- \\
119\end{array}$ & 11,59 & $13-14$ & 1,34 \\
\hline$\%$ & 0,79 & 1,02 & $/ 1$ & 0,05 & $\pi$ & - & $/ 1$ & 0,77 & $\pi$ & 8,23 & $\pi$ & & $\pi$ \\
\hline Srem & $\begin{array}{r}8.266- \\
8.796 \\
\end{array}$ & $\begin{array}{r}4.536- \\
4.827 \\
\end{array}$ & 54,87 & $\begin{array}{r}1.090 \\
1.160 \\
\end{array}$ & 13,19 & $\begin{array}{r}2.538- \\
2.701 \\
\end{array}$ & 30,70 & $\begin{array}{r}91- \\
96 \\
\end{array}$ & 1,10 & - & - & $11-12$ & 0,13 \\
\hline$\%$ & 6,76 & 5,89 & $/ /$ & 6,08 & $/ /$ & 13,42 & $/ /$ & 1,51 & $/ /$ & - & $1 /$ & & $/ /$ \\
\hline Ukupno & $\begin{array}{r}122.279 \\
130.120 \\
\end{array}$ & \begin{tabular}{|r|}
$77.011-$ \\
81.950 \\
\end{tabular} & 62,98 & \begin{tabular}{|r|}
$17.926-$ \\
19.076 \\
\end{tabular} & 14,66 & \begin{tabular}{|r|}
$18.916-$ \\
20.129 \\
\end{tabular} & 15,47 & \begin{tabular}{|c|}
$6004-$ \\
6.389 \\
\end{tabular} & 4,91 & \begin{tabular}{|r|}
$1.357-$ \\
1.444 \\
\end{tabular} & 1,11 & \begin{tabular}{|r|}
$1.064-$ \\
1.132 \\
\end{tabular} & 0,87 \\
\hline
\end{tabular}

Proračun na osnovu baze podataka „Žrtve rata 1941-1945“ 
U Jasenovcu pretrpljeni gubici pojedinih nacionalnosti iz različitih delova NDH nisu bili u skladu sa njihovom zastupljenošću u populaciji tih regiona. Tako su Srbi iz devet regiona imali veće učešće u gubicima u Jasenovcu nego što im je bilo učešće u populaciji regiona, najviše u delu Dalmacije 5,36 puta, Severozapadnoj Hrvatskoj 3,80 puta, Hercegovina 2,53 puta, Slavonija 2,40 puta, ${ }^{26}$ dok im je u tri regiona učešće bilo izjednačeno, Gorskom kotaru sa hrvatskim primorjem, Istočnoj Bosni i Sremu. ${ }^{27}$ Uništavanje Jevreja i Roma ${ }^{28} \mathrm{u}$ skladu sa rasnim zakonima NDH prouzrokovalo je da su njihova učešća u gubicima u Jasenovcu bila u svim regionima višestruko veća od njihove zastupljenosti u tamošnjoj populaciji, Jevreja u Srednjoj Bosni 67,37 puta, Istočnoj Bosni 52,71 puta, Severozapadnoj Hrvatskoj 35,85 puta, Sremu 30,67 puta, Slavoniji 10,38 puta. Hrvati i Muslimani iz svih delova NDH su imali višestruko manja učešća u gubicima u Jasenovcu nego što im je bila zastupljenost u populaciji regiona iz kojeg su poticali, Hrvati Like 1,27 puta, Severozapadne Hrvatske i dela Dalmacije 3,40 odnosno 3,37 puta, Banije i Korduna 8,08 odnosno 10,47 puta, Hercegovine 9,43 puta, Slavonije i Srema 12,89 odnosno 11,16 puta, Istočne Bosne 13,22 puta, Bosanske Krajine 17,19 puta, Srednje Bosne 24,18 puta manje, dok je učešće u gubicima Muslimana iz Hercegovine i Srednje Bosne bilo 1,97 odnosno 4,64 puta manje, a Bosanske Krajine i Istočne Bosne 12,63 odnosno 13,22 puta manje.

Nejednaki gubici iz različitih delova NDH pretrpljeni u Jasenovcu uslovili su i nejednako stradanje, kako različitih nacionalnosti koje su živele u tim regionima, tako i u okviru istih nacionalnosti. U okviru svake nacionalnosti zastupljene u gubicima u Jasenovcu, postojale su razlike u veličini pretrpljenog gubitka sunarodnika iz različitih delova NDH u odnosu na njihov udeo u nacionalnom korpusu, zatim razlike u udelu stradalih u Jasenovcu i na ostalim stratištima, kao i razlike u zastupljenosti u gubicima u Jasenovcu i u gubicima pretrpljenim na ostalim i nepoznatim mestima.

Srbi stradali u Jasenovcu su poticali iz svih delova NDH, ali njihovo stradanje nije bilo jednako. Tri četvrtine u Jasenovcu stradalih Srba $(74,61 \%)$ poticalo je iz tri regiona. Gotovo dve petine stradalih civila srpske nacionalnosti poticalo je iz Bosanske Krajine, više od četvrtine iz Slavonije, skoro devetina sa Banije, uz trinaesti deo koji je poticao iz Istočne Bosne i sedamnaesti iz Srema, dok je učešće stradalih Srba iz ostalih sedam regiona bilo manje ili minimalno. ${ }^{29}$

\footnotetext{
${ }^{26}$ Srednja Bosna 2,28 puta, Banija 1,78, Bosanska Krajina 1,48, Kordun 1,29, Lika 1,14 puta.

${ }^{27}$ Zapravo učešće u gubicima u logoru u Istočnoj Bosni i Sremu je bilo neznatno manje, 1,02 odnosno 1,06 puta, od zastupljenosti Srba u stanovništvu tih regiona.

${ }^{28}$ Zbog nepostojanja preciznih podataka o teritorijalnom rasporedu Roma nismo u mogućnosti da prikažemo tačne podatke o njihovim realnim gubicima po regionima.

${ }^{29}$ U Jasenovcu su stradali Srbi iz Hercegovine, Like, dela Gorskog kotara sa hrvatskim primorjem i dela Dalmacije činili $1,83 \%$ u logoru stradalih sunarodnika.
} 
Tabela 8. NDH, Srbi - učešće u nacionalnom korpusu i gubicima u Jasenovcu

\begin{tabular}{|l|r|r|}
\hline NDH - Srbi & $\begin{array}{c}\text { \% učešće } u \\
\text { nacionalnom } \\
\text { korpusu }\end{array}$ & $\begin{array}{c}\text { \% među } \\
\text { stradalim } \mathrm{u} \\
\text { Jasenovcu }\end{array}$ \\
\hline $\begin{array}{l}\text { Severozapadna } \\
\text { Hrvatska }\end{array}$ & 2,48 & 2,15 \\
\hline Slavonija & 10,46 & 27,20 \\
\hline Banija & 5,17 & 10,53 \\
\hline Kordun & 4,81 & 3,38 \\
\hline Lika & 5,42 & 0,28 \\
\hline deo Gorskog kotara sa \\
hrvatskim primorjem & 1,46 & 0,15 \\
\hline deo Dalmacije & 2,67 & 0,38 \\
\hline Bosanska Krajina & 22,97 & 36,88 \\
\hline Srednja Bosna & 9,14 & 4,23 \\
\hline Istočna Bosna & 19,56 & 7,91 \\
\hline Hercegovina & 5,51 & 1,02 \\
\hline Srem & 10,34 & 5,89 \\
\hline
\end{tabular}

Popis stanovništva 1931. i proračun na osnovu baze podataka „Žrtve rata 1941-1945“

Pretrpljeni gubici u logoru Srba iz različitih delova NDH nisu uvek bili u skladu sa njihovom zastupljenošću u nacionalnom korpusu, odnosno sa veličinom dela srpskog naroda koji je živeo u regionu iz kojeg su stradali poticali. Srbi iz tri od dvanaest regiona su imali nesrazmerno veliko stradanje, iz Slavonije 2,60 puta veće, sa Banije 2,04 puta i iz Bosanske Krajine 1,60 puta veće učešće u gubicima u Jasenovcu od zastupljenosti u nacionalnom korpusu, dok je učešće u gubicima stradalih iz ostalih devet regiona bilo manje, od 1,15 odnosno 1,42 puta Severozapadne Hrvatske i Korduna, do 9,73 odnosno 19,35 puta manje iz dela Gorskog kotara sa hrvatskim primorjem i Like. ${ }^{30}$ Time je pretrpljeni gubitak u Jasenovcu Srba iz Slavonije bio realno 1,28 odnosno 1,63 puta veći od gubitka sunarodnika sa Banije i iz Bosanske Krajine, 4,57 odnosno 6,43 puta veći od gubitaka Srba iz Srema i Istočne Bosne, ali i 50,33 puta veći od gubitka sunarodnika iz Like.

Uloga logora Jasenovac u uništavanju Srba iz različitih delova NDH nije bila jednaka, ali je za civile srpske nacionalnosti iz najmanje šest regiona on bio primarno mesto stradanja. Gotovo tri petine stradalih civila srpske nacionalnosti iz Slavonije izgubilo je život u Jasenovcu, čime je njihovo stradanje u logoru bilo za četvrtinu veće (1,25 puta) od stradanja na svim drugim mestima zajedno. U ovom logoru je stradala i po trećina njihovih sunarodnika iz Severozapadne Hrvatske i sa Banije, kao i po četvrtina iz Srema i Bosanske Krajine, te petina iz Srednje Bosne, sedmina iz Istočne Bosne, dok je udeo stradalih u Jasenovcu iz ostalih regiona bio daleko manji ili minimalan (Lika). Time je među

\footnotetext{
${ }^{30}$ Manje učešće u gubicima u Jasenovcu od zastupljenosti u srpskom nacionalnom korpusu imali su Srbi iz Srema 1,75 puta, Srednje i Istočne Bosne 2,16 odnosno 2,47 puta, Hercegovine 5,40 i dela Dalmacije 7,03 puta.
} 
Srbima iz Slavonije udeo stradalih u Jasenovcu bio 1,65 puta veći nego kod sunarodnika sa Banije, 2,36 odnosno 3,70 puta nego kod Srba iz Bosanske Krajine i Istočne Bosne, ali i 62,40 puta veći nego kod sunarodnika iz Like.

Tabela 9. NDH, civili, Srbi - mesta stradanja prema teritorijalnoj pripadnosti

\begin{tabular}{|c|c|c|c|c|c|}
\hline $\begin{array}{c}\text { NDH, civili - } \\
\text { Srbi }\end{array}$ & Ukupno & $\begin{array}{l}\text { Stradali u } \\
\text { Jasenovcu }\end{array}$ & $\%$ & $\begin{array}{c}\text { Ostalim i } \\
\text { nepoznatim } \\
\text { mestima }\end{array}$ & $\%$ \\
\hline $\begin{array}{l}\text { Severozapadna } \\
\text { Hrvatska }\end{array}$ & $\begin{array}{r}4.876- \\
5.179\end{array}$ & $\begin{array}{r}1.656- \\
1.762\end{array}$ & 33,99 & $3.220-3.417$ & 66,01 \\
\hline$\%$ & 1,47 & 2,15 & // & 1,26 & // \\
\hline Slavonija & $\begin{array}{r}37.751- \\
40.097\end{array}$ & $\begin{array}{r}20.947- \\
22.290\end{array}$ & 55,54 & $\begin{array}{r}16.804- \\
17.807\end{array}$ & 44,46 \\
\hline$\%$ & 11,38 & 27,20 & // & 6,59 & // \\
\hline Banija & $\begin{array}{r}24.084- \\
25.580 \\
\end{array}$ & $\begin{array}{r}8.109- \\
8.629 \\
\end{array}$ & 33,70 & $\begin{array}{r}15.975- \\
16.951 \\
\end{array}$ & 66,30 \\
\hline$\%$ & 7,26 & 10,53 & // & 6,27 & // \\
\hline Kordun & $\begin{array}{r}28.496- \\
30.266 \\
\end{array}$ & $\begin{array}{r}2.603- \\
2.770 \\
\end{array}$ & 9,14 & $\begin{array}{r}25.893- \\
27.496 \\
\end{array}$ & 90,86 \\
\hline$\%$ & 8,59 & 3,38 & // & 10,17 & // \\
\hline Lika & $\begin{array}{r}24.349- \\
25.862\end{array}$ & $216-230$ & 0,89 & $\begin{array}{r}24.133- \\
25.63\end{array}$ & 99,12 \\
\hline$\%$ & 7,34 & 0,28 & // & 9,48 & // \\
\hline $\begin{array}{l}\text { deo Gorskog } \\
\text { kotara sa } \\
\text { hrvatskim } \\
\text { primorjem }\end{array}$ & $\begin{array}{r}3.814 \\
4.052\end{array}$ & $115-123$ & 3,02 & $3.699-3.929$ & 96,98 \\
\hline$\%$ & 1,15 & 0,15 & /1 & 1,45 & // \\
\hline deo Dalmacije & $\begin{array}{r}2.621- \\
2.783 \\
\end{array}$ & $293-311$ & 11,17 & $2.328-2.472$ & 88,83 \\
\hline$\%$ & 0,79 & 0,38 & /1 & 0,91 & /1 \\
\hline $\begin{array}{l}\text { Bosanska } \\
\text { Krajina } \\
\end{array}$ & $\begin{array}{r}120.984 \\
128.500 \\
\end{array}$ & $\begin{array}{r}28.402- \\
30.223 \\
\end{array}$ & 23,50 & $\begin{array}{r}92.582- \\
98.277 \\
\end{array}$ & 76,50 \\
\hline$\%$ & 36,47 & 36,88 & /1 & 36,35 & // \\
\hline Srednja Bosna & $\begin{array}{r}15.956- \\
16.948 \\
\end{array}$ & $\begin{array}{r}3.258- \\
3.466 \\
\end{array}$ & 20,44 & $\begin{array}{r}12.698- \\
13.482 \\
\end{array}$ & 79,56 \\
\hline$\%$ & 4,81 & 4,23 & /1 & 4,99 & $/ 1$ \\
\hline Istočna Bosna & $\begin{array}{r}40.604- \\
43.127 \\
\end{array}$ & $\begin{array}{r}6.092- \\
6.482 \\
\end{array}$ & 15,02 & $\begin{array}{r}34.512- \\
36.645 \\
\end{array}$ & 84,98 \\
\hline$\%$ & 12,24 & 7,91 & // & 13,55 & // \\
\hline Hercegovina & $\begin{array}{r}12.175- \\
12.931 \\
\end{array}$ & $786-836$ & 6,45 & $\begin{array}{r}11.389- \\
12.095 \\
\end{array}$ & 93,55 \\
\hline$\%$ & 3,67 & 1,02 & // & 4,47 & // \\
\hline Srem & $\begin{array}{r}16.022- \\
17.018 \\
\end{array}$ & $\begin{array}{r}4.536- \\
4.827 \\
\end{array}$ & 28,34 & $\begin{array}{r}11.486- \\
12.191 \\
\end{array}$ & 71,66 \\
\hline$\%$ & 4,83 & 5,89 & /1 & 4,51 & /1 \\
\hline ukupno & $\begin{array}{r}331.735- \\
352.344 \\
\end{array}$ & $\begin{array}{r}77.011- \\
81.950 \\
\end{array}$ & 23,24 & $\begin{array}{r}254.724- \\
270.394 \\
\end{array}$ & 76,76 \\
\hline
\end{tabular}

Proračun na osnovu baze podataka „Žrtve rata 1941-1945“ 
Stradali civili srpske nacionalnosti iz različitih delova NDH su uglavnom imali različitu zastupljenost u gubicima u Jasenovcu i na ostalim mestima. Srbi iz Bosanske Krajine su imali isto učešće u gubicima u Jasenovcu i na ostalim mestima, njihovi sunarodnici iz Slavonije su imali 4,13 puta veću zastupljenost u gubicima u Jasenovcu, kao i Srbi iz Severozapadne Hrvatske 1,71 puta, sa Banije 1,68 puta i iz Srema 1,30 puta veću, dok su civili srpske nacionalnosti iz ostalih sedam regiona imali manje učešće u gubicima u Jasenovcu od učešća u gubicima na drugim mestima, Srednje i Istočne Bosne 1,18 odnosno 1,71 puta, dela Dalmacije i Korduna 2,39 odnosno 3,01 puta, Hercegovine 4,38 puta, dela Gorskog kotara sa hrvatskim primorjem 9,67 puta i Like 33,86 puta manje.

Tabela 10. NDH, Jevreji - mesta stradanja prema teritorijalnoj pripadnosti

\begin{tabular}{|c|c|c|c|c|c|}
\hline $\begin{array}{l}\text { NDH, civili - } \\
\text { Jevreji }\end{array}$ & Ukupno & $\begin{array}{l}\text { Stradali u } \\
\text { Jasenovcu }\end{array}$ & $\%$ & $\begin{array}{l}\text { Ostalim i } \\
\text { nepoznatim } \\
\text { mestima }\end{array}$ & $\%$ \\
\hline $\begin{array}{l}\text { Severozapadna } \\
\text { Hrvatska }\end{array}$ & $\begin{array}{r}10.633- \\
11.293\end{array}$ & $\begin{array}{r}3.813- \\
4.057\end{array}$ & 35,89 & $6.820-7.236$ & 64,11 \\
\hline$\%$ & 36,55 & 21,27 & /1 & 61,15 & $\pi$ \\
\hline Slavonija & $\begin{array}{r}6.112- \\
6.492\end{array}$ & $\begin{array}{r}3.340- \\
3.554\end{array}$ & 54,69 & $2.772-2.938$ & 45,31 \\
\hline$\%$ & 21,01 & 18,63 & /1 & 24,84 & // \\
\hline Bosanska Krajina & $407-432$ & $249-265$ & 61,26 & $158-167$ & 38,74 \\
\hline$\%$ & 1,40 & 1,39 & $/ /$ & 1,41 & $/ /$ \\
\hline Srednja Bosna & $817-868$ & $706-752$ & 86,52 & $111-116$ & 13,48 \\
\hline$\%$ & 2,81 & 3,94 & $/ /$ & 0,98 & $/ /$ \\
\hline Istočna Bosna & $\begin{array}{l}9.423- \\
10.008\end{array}$ & $\begin{array}{r}8.542- \\
9.090\end{array}$ & 90,74 & $881-918$ & 9,26 \\
\hline$\%$ & 32,39 & 47,65 & // & 7,83 & $/ 1$ \\
\hline Srem & $\begin{array}{r}1.213- \\
1.288\end{array}$ & $\begin{array}{r}1.090- \\
1.160\end{array}$ & 89,96 & $123-128$ & 10,04 \\
\hline$\%$ & 4,17 & 6,08 & $/ /$ & 1,09 & // \\
\hline \multirow[t]{2}{*}{ ostalih 6 regiona } & $486-516$ & 186-198 & 38,32 & $300-318$ & 61,68 \\
\hline & 1,67 & 1,04 & $/ /$ & 2,69 & $/ /$ \\
\hline ukupno & $\begin{array}{r}29.092- \\
30.899 \\
\end{array}$ & $\begin{array}{r}17.926- \\
19.076 \\
\end{array}$ & 61,68 & $\begin{array}{r}11.166- \\
11.823 \\
\end{array}$ & 38,32 \\
\hline
\end{tabular}

Proračun na osnovu baze podataka „Žrtve rata 1941-1945“

Polovinu svih Jevreja iz NDH stradalih u Jasenovcu predstavljali su pripadnici ove nacionalne zajednice iz Istočne Bosne, uz po petinu iz Severozapadne Hrvatske i Slavonije, dok ih je osmina $(12,45 \%)$ poticala iz ostalih devet regiona. Zastupljenost u gubicima u logoru Jevreja iz različitih delova NDH nije uvek bila u skladu sa njihovim udelom u nacionalnom korpusu. Tako su Jevreji iz Istočne Bosne i Srema imali učešće u gubicima u logoru 1,66 odnosno 1,39 puta veće od njihove zastupljenosti u nacionalnom korpusu, sunarodnici iz Srednje Bosne su imali izjednačena učešća, dok su Jevreji iz drugih delova NDH imali učešće u gubicima u logoru manje od njihove zastupljenosti u naci- 
onalnom korpusu, Slavonije 1,17 puta, Severozapadne Hrvatske 1,65 puta, Bosanske Krajine 1,72 puta i iz ostalih šest regiona 3,74 puta. Time je gubitak Jevreja iz Istočne Bosne i Srema pretrpljen u Jasenovcu bio realno 2,73 odnosno 2,28 puta veći od gubitka sunarodnika iz Severozapadne Hrvatske i 1,94 odnosno 1,63 puta veći od gubitka Jevreja iz Slavonije.

U holokaustu stradali Jevreji iz različitih delova NDH nisu imali isti udeo stradalih u Jasenovcu u ukupnim gubicima sunarodnika iz tih regiona. Tri regiona sa najvećim brojem stradalih Jevreja imala su potpuno drugačiji udeo gubitaka $u$ Jasenovcu. Dok su iz Istočne Bosne gotovo svi Jevreji izgubili živote u Jasenovcu, od njihovih sunarodnika iz Slavonije i Severozapadne Hrvatske svega je polovina odnosno trećina stradala $u$ tom logoru. ${ }^{31}$ Time je udeo stradalih u Jasenovcu u gubicima Jevreja Istočne Bosne bio 1,66 odnosno 2,53 puta veći od udela u gubicima sunarodnika iz Slavonije i Severozapadne Hrvatske. Sa apsolutnom većinom pretrpljenih gubitaka u njemu, Jasenovac je predstavljao primarno mesto stradanja za Jevreje Srema, srednje Bosne i Bosanske Krajine, dok je u njemu život izgubilo dve petine Jevreja iz ostalih šest regiona NDH.

Jevreji iz različitih delova NDH nisu imali jednako učešće u gubicima u Jasenovcu i u gubicima na drugim mestima. Činivši polovinu stradalih sunarodnika u Jasenovcu, Jevreji istočne Bosne su imali 6,08 puta veće učešće u gubicima u ovom logoru nego na drugim stratištima. Poput njih veće učešće u gubicima u Jasenovcu imali su i pripadnici jevrejske zajednice Srema (5,58 puta) i Srednje Bosne (4,02 puta). Nasuprot njima, Jevreji iz Severozapadne Hrvatske i Slavonije su imali 2,87 odnosno 1,33 puta manju zastupljenost u gubicima u Jasenovcu nego u gubicima na drugim mestima, kao što je to bio i slučaj sa pripadnicima jevrejske zajednice iz ostalih šest regiona (2,59 puta). Jedino su Jevreji iz Bosanske Krajine imali isto učešće u gubicima u Jasenovcu i na ostalim mestima.

Rasnim zakonima određeni za uništenje u NDH, Romi su trpeli gubitke u svim delovima NDH, a Jasenovac je za većinu predstavljao primarno mesto stradanja. Tri petine stradalih Roma u Jasenovcu je poticalo iz Slavonije, sedmina iz Srema, uz desetinu iz Severozapadne Hrvatske, dok ih je šestina poticala iz ostalih devet regiona NDH.

Logor u Jasenovcu je predstavljao centralno mesto uništavanja Roma NDH. U njemu je život izgubilo po četiri petine od svih stradalih Roma iz Slavonije, Srema i Severozapadne Hrvatske, dve trećine stradalih sunarodnika sa Korduna, te više od polovine stradalih iz ostalih osam regiona NDH. Time je udeo u Jasenovcu stradalih Roma iz Slavonije, ali i Srema i Severozapadne Hrvatske, bio 1,25 puta veći od udela u njemu stradalih sunarodnika sa Korduna i 1,52 puta veći od udela logora u gubicima stradalih Roma iz Bosanske Krajine.

\footnotetext{
${ }^{31}$ Među Jevrejima Severozapadne Hrvatske koji su stradali na ostalim mestima 56,80\% izgubilo je živote u nemačkim logorima van teritorije Jugoslavije, 29,21\% u Gospićkoj grupi logora (Gospić, Jadovno, Pag), 13,99\% na drugim mestima, dok je među Jevrejima iz Slavonije stradalim na ostalim mestima $84,91 \%$ izgubilo živote u logorima u Trećem rajhu.
} 
Tabela 11. NDH, Romi - mesta stradanja prema teritorijalnoj pripadnosti

\begin{tabular}{|c|c|c|c|c|c|}
\hline $\begin{array}{l}\text { NDH, civili - } \\
\text { Romi }\end{array}$ & Ukupno & $\begin{array}{l}\text { Stradali u } \\
\text { Jasenovcu }\end{array}$ & $\%$ & $\begin{array}{c}\text { Ostalim i } \\
\text { nepoznatim } \\
\text { mestima }\end{array}$ & $\%$ \\
\hline $\begin{array}{l}\text { Severozapadna } \\
\text { Hrvatska }\end{array}$ & $\begin{array}{r}2.333- \\
2.478\end{array}$ & $\begin{array}{r}1.941- \\
2.065\end{array}$ & 83,26 & $392-413$ & 16,74 \\
\hline$\%$ & 9,62 & 10,26 & // & 7,34 & // \\
\hline Slavonija & $\begin{array}{r}13.607- \\
14.453\end{array}$ & $\begin{array}{r}11.340- \\
12.067\end{array}$ & 83,42 & $2.267-2.386$ & 16,58 \\
\hline$\%$ & 56,11 & 59,95 & // & 42,44 & $/ /$ \\
\hline Kordun & $\begin{array}{r}2.124- \\
2.256\end{array}$ & $\begin{array}{r}1.413- \\
1.504\end{array}$ & 66,59 & $711-752$ & 33,41 \\
\hline$\%$ & 8,76 & 7,47 & // & 13,35 & $/ /$ \\
\hline $\begin{array}{l}\text { Bosanska } \\
\text { Krajina }\end{array}$ & $\begin{array}{r}2.003- \\
2.128\end{array}$ & $\begin{array}{r}1.097- \\
1.167\end{array}$ & 54,81 & $906-961$ & 45,19 \\
\hline$\%$ & 8,26 & 5,80 & $/ /$ & 17,03 & $/ /$ \\
\hline Srem & $\begin{array}{r}3.092- \\
3.284\end{array}$ & $\begin{array}{r}2.538- \\
2.701\end{array}$ & 82,16 & $554-583$ & 17,84 \\
\hline$\%$ & 12,75 & 13,42 & $/ /$ & 10,37 & $/ 1$ \\
\hline $\begin{array}{l}\text { ostalih } 7 \\
\text { regiona }\end{array}$ & $\begin{array}{r}1.091- \\
1.159 \\
\end{array}$ & $587-625$ & 53,86 & $504-534$ & 46,14 \\
\hline$\%$ & 4,50 & 3,10 & // & 9,47 & $/ /$ \\
\hline ukupno & $\begin{array}{r}24.251- \\
25.758\end{array}$ & $\begin{array}{r}18.916- \\
20.129\end{array}$ & 78,08 & $5.335-5.629$ & 21,92 \\
\hline
\end{tabular}

Proračun na osnovu baze podataka „Žrtve rata 1941-1945“

Zastupljenost Roma iz različitih delova NDH u gubicima u Jasenovcu i na ostalim mestima nije bila ista. Romi iz tri regiona iz kojih je poticao najveći deo stradalih imali su veće učešće u gubicima u Jasenovcu nego na drugim mestima, Slavoniji i Severozapadnoj Hrvatskoj 1,41 odnosno 1,40 puta i Sremu 1,29 puta, dok su njihovi sunarodnici iz drugih delova imali veću zastupljenost u gubicima na ostalim mestima nego u ovom logoru, sa Korduna 1,79 puta, a iz Bosanske Krajine i ostalih šest regiona 2,94 odnosno 3,05 puta.

U obračunu sa političkim i ideološkim protivnicima režima NDH je Jasenovac koristila za eliminaciju ,nepodobnih“ Hrvata iz svih njenih delova, s time što je tri četvrtine gubitaka poticalo iz dva regiona, polovina iz Severozapadne Hrvatske i četvrtina iz Slavonije. Zastupljenost Hrvata iz pojedinih delova NDH u gubicima u Jasenovcu nije uvek bila u skladu sa njihovim udelom u nacionalnom korpusu. Tako je učešće u gubicima Hrvata sa Banije bilo 2,70 puta veće od njihove zastupljenosti u nacionalnom korpusu, Slavonije 1,60 puta, Severozapadne Hrvatske i Bosanske Krajine 1,25 odnosno 1,20 puta veće, učešće sunarodnika sa Korduna je bilo izjednačeno, dok je zastupljenost Hrvata iz ostalih sedam regiona NDH u gubicima u Jasenovcu bila 3,10 puta manja od njihovog udela u nacionalnom korpusu (37,14\%). Time je gubitak Hrvata sa Banije pretrpljen u Jasenovcu bio realno 1,68 puta veći od gubitka sunarodnika iz Slavonije, 2,15 odnosno 2,25 puta veći od gubitaka Hrvata iz Severozapadne 
Hrvatske i Bosanske Krajine, 2,73 puta veći od gubitaka sunarodnika sa Korduna, ali i 26,34 puta veći od gubitka Hrvata iz ostalih sedam regiona NDH.

Tabela 12. NDH, Hrvati - mesta stradanja prema teritorijalnoj pripadnosti

\begin{tabular}{|c|c|c|c|c|c|}
\hline $\begin{array}{l}\text { NDH, civili - } \\
\text { Hrvati }\end{array}$ & Ukupno & $\begin{array}{l}\text { Stradali u } \\
\text { Jasenovcu }\end{array}$ & $\%$ & $\begin{array}{c}\text { Ostalim i } \\
\text { nepoznatim } \\
\text { mestima }\end{array}$ & $\%$ \\
\hline $\begin{array}{l}\text { Severozapadna } \\
\text { Hrvatska }\end{array}$ & $\begin{array}{r}17.219- \\
18.288\end{array}$ & $\begin{array}{r}2.757- \\
2.934\end{array}$ & 16,03 & $\begin{array}{r}14.462- \\
15.354\end{array}$ & 83,97 \\
\hline$\%$ & 33,83 & 45,92 & // & 32,21 & // \\
\hline Slavonija & $\begin{array}{r}7.569- \\
8.039\end{array}$ & $\begin{array}{r}1.603- \\
1.706\end{array}$ & 21,20 & $5.966-6.333$ & 78,80 \\
\hline$\%$ & 14,87 & 26,70 & $/ /$ & 13,29 & // \\
\hline Banija & $\begin{array}{r}1.934- \\
2.054\end{array}$ & $511-544$ & 26,45 & $1.423-1.510$ & 73,55 \\
\hline$\%$ & 3,80 & 8,51 & // & 3,17 & // \\
\hline Kordun & $\begin{array}{r}1.893- \\
2.011 \\
\end{array}$ & $223-237$ & 11,78 & $1.670-1.774$ & 88,22 \\
\hline$\%$ & 3,72 & 3,71 & // & 3,72 & // \\
\hline $\begin{array}{l}\text { Bosanska } \\
\text { Krajina }\end{array}$ & $\begin{array}{r}1.557- \\
1.654\end{array}$ & $190-202$ & 12,20 & $1.367-1.452$ & 87,80 \\
\hline$\%$ & 3,06 & 3,17 & // & 3,04 & // \\
\hline ostalih 7 regiona & $\begin{array}{r}20.726- \\
22.013 \\
\end{array}$ & $720-766$ & 3,47 & $\begin{array}{r}20.006- \\
21.247 \\
\end{array}$ & 96,53 \\
\hline$\%$ & 40,72 & 11,99 & $/ /$ & 44,57 & $/ /$ \\
\hline ukupno & $\begin{array}{r}50.898- \\
54.060 \\
\end{array}$ & $\begin{array}{r}6.004- \\
6.389\end{array}$ & 11,81 & $\begin{array}{r}44.894- \\
47.671 \\
\end{array}$ & 88,19 \\
\hline
\end{tabular}

Proračun na osnovu baze podataka „Žrtve rata 1941-1945“

U Jasenovcu stradali Hrvati iz različitih delova NDH nisu imali isti udeo u gubicima svojih regiona. U njemu je život izgubila četvrtina stradalih sa Banije, petina iz Slavonije, šestina iz Severozapadne Hrvatske, osmina iz Bosanske Krajine i sa Korduna, dok je udeo stradalih u njemu iz ostalih sedam regiona bio minimalan. Time je udeo stradalih u Jasenovcu u gubicima Hrvata sa Banije bio 1,25 odnosno 1,65 puta veći od udela u gubicima sunarodnika iz Slavonije i Severozapadne Hrvatske, ali i 7,62 puta veći od udela u logoru stradalih Hrvata iz ostalih sedam regiona NDH.

Stradali civili hrvatske nacionalnosti iz različitih delova NDH su uglavnom imali različitu zastupljenost u gubicima u Jasenovcu i na ostalim mestima, sa izuzetkom civila sa Korduna i iz Bosanske Krajine kod kojih je učešće bilo izjednačeno. Učešće u gubicima u Jasenovcu Hrvata sa Banije je bilo 2,68 puta veće od njihove zastupljenosti u gubicima na drugim mestima, Slavonije i Severozapadne Hrvatske 2,01 odnosno 1,42 puta, dok je zastupljenost civila hrvatske nacionalnosti iz ostalih sedam regiona u gubicima u Jasenovcu bila 3,72 puta manja nego na ostalim i nepoznatim mestima.

Logor u Jasenovcu je korišćen za obračun sa politički i ideološki „nepodobnim" Muslimanima i u njega su dovođeni logoraši iz čitave NDH. Više od 
dve petine odnosno petine svih stradalih Muslimana u Jasenovcu poticalo je iz Bosanske Krajine i Istočne Bosne, uz šestinu iz Srednje Bosne i dvanaestinu iz Hercegovine. Zastupljenost u gubicima u logoru Muslimana iz različitih delova NDH nije uvek bila u skladu sa njihovim udelom u nacionalnom korpusu, pa je kod onih iz Bosanske Krajine bila 1,98 puta veća, ${ }^{32}$ Srednje Bosne izjednačena, dok je učešće u gubicima u logoru Muslimana iz Istočne Bosne i Hercegovine bilo 1,73 odnosno 1,18 puta manje od udela u nacionalnom korpusu. Time je u Jasenovcu pretrpljeni gubitak Muslimana iz Bosanske Krajine bio realno 1,97 odnosno 2,33 puta veći od gubitka sunarodnika iz Srednje Bosne i Hercegovine, ali i 3,41 puta veći od gubitka Muslimana iz Istočne Bosne.

Tabela 13 - NDH, Muslimani - mesta stradanja prema teritorijalnoj pripadnosti

\begin{tabular}{|c|c|c|c|c|c|}
\hline $\begin{array}{l}\text { NDH, civili - } \\
\text { Muslimani }\end{array}$ & Ukupno & $\begin{array}{l}\text { Stradali u } \\
\text { Jasenovcu }\end{array}$ & $\%$ & $\begin{array}{c}\text { Ostalim i } \\
\text { nepoznatim } \\
\text { mestima }\end{array}$ & $\%$ \\
\hline $\begin{array}{l}\text { Bosanska } \\
\text { Krajina }\end{array}$ & $\begin{array}{r}4.482- \\
4.760\end{array}$ & $586-624$ & 13,09 & $3.896-4.136$ & 86,81 \\
\hline$\%$ & 11,56 & 43,22 & $/ /$ & 10,41 & /1 \\
\hline Srednja Bosna & $\begin{array}{r}3.005- \\
3.191\end{array}$ & $243-259$ & 8,11 & $2.762-2.932$ & 91,89 \\
\hline$\%$ & 7,75 & 17,92 & $/ /$ & 7,38 & $/ /$ \\
\hline Istočna Bosna & $\begin{array}{r}28.358- \\
30.120 \\
\end{array}$ & $393-418$ & 1,39 & $\begin{array}{r}27.965- \\
29.702 \\
\end{array}$ & 98,61 \\
\hline$\%$ & 73,14 & 28,93 & $/ /$ & 74,74 & $/ /$ \\
\hline Hercegovina & $\begin{array}{r}2.846- \\
3.023 \\
\end{array}$ & $112-119$ & 3,94 & $2.734-2.904$ & 96,06 \\
\hline$\%$ & 7,34 & 8,23 & $/ /$ & 7,31 & $/ /$ \\
\hline $\begin{array}{l}\text { ostalih } 8 \\
\text { regiona }\end{array}$ & $81-86$ & $23-24$ & 28,15 & $58-62$ & 71,85 \\
\hline$\%$ & 0,21 & 1,70 & // & 0,16 & // \\
\hline ukupno & $\begin{array}{r}38.772- \\
41.181 \\
\end{array}$ & $\begin{array}{r}1.357- \\
1.444 \\
\end{array}$ & 3,50 & $\begin{array}{r}37.415- \\
39.737 \\
\end{array}$ & 96,50 \\
\hline
\end{tabular}

Proračun na osnovu baze podataka ,Žrtve rata 1941-1945“

Opšti mali udeo stradalih u Jasenovcu među Muslimanima iz NDH nije bio jednak u svim njenim delovima. Osmina svih stradalih Muslimana Bosanske Krajine i dvanaestina iz Srednje Bosne izgubila je živote u Jasenovcu, dok je udeo stradalih iz ostala dva regiona bio minimalan. ${ }^{33}$ Time je udeo u gubicima Muslimana iz Bosanske Krajine stradalih u Jasenovcu bio 1,61 puta veći od udela sunarodnika iz Srednje Bosne, ali i 3,32 odnosno 9,42 puta veći od udela Muslimana iz Hercegovine i Istočne Bosne.

\footnotetext{
${ }^{32}$ Kod malobrojnih Muslimana iz NDH koji su živeli van Bosne i Hercegovine zastupljenost u gubicima u Jasenovcu bila je 2,61 puta veća od njihovog učešća u nacionalnom korpusu.

${ }^{33}$ Među malobrojnim Muslimanima koji su živeli van ova četiri regiona udeo stradalih u Jasenovcu bio je veći od četvrtine ukupnih gubitaka civila.
} 
Učešće u gubicima u Jasenovcu i u gubicima pretrpljenim na drugim mestima nije bilo jednako kod civila muslimanske nacionalnosti iz različitih delova NDH. U tri od četiri regiona Muslimani su imali veće učešće u gubicima u Jasenovcu nego na ostalim mestima, Bosanskoj Krajini 4,15 puta, Srednjoj Bosni 2,43 puta i Hercegovini 1,12 puta, ali je u Istočnoj Bosni, iz koje je poticalo tri četvrtine svih žrtava civila muslimanske nacionalnosti, učešće stradalih u Jasenovcu bilo 2,58 puta manje od učešća u gubicima pretrpljenim na drugim mestima.

Logor Jasenovac, odnosno sistem logora, predstavljao je najveći koncentracioni logor u NDH u kojem je život izgubila četvrtina svih stradalih civila ove teritorije $(24,53 \%)$. Obim izvršenog zločina u logoru Jasenovac jasno ga je odredio kao logor uništenja. Stradali u Jasenovcu dovođeni su u logor iz svih delova NDH. Najveći deo stradalih je poticao iz dva regiona sa kojima se logor graničio, 30,60\% iz Slavonije i 25,13\% iz Bosanske Krajine, uz 12,62\% gubitaka koji su poticali iz Istočne Bosne. Stradali iz 4 regiona su imali veće učešće u gubicima u Jasenovcu nego što je bila njihova zastupljenost u populaciji NDH, Banija 2,25 puta, Bosanska Krajina 2,14 puta, Slavonija 2,13 puta i Srem 1,19 puta. Kordun je predstavljao jedini region NDH koji je imao približno isto učešće u gubicima u logoru sa učešćem u stanovništvu. Stradali iz ostalih 7 regiona NDH su imali daleko manje učešće u gubicima u Jasenovcu od njihove zastupljenosti u populaciji, od 19,12 odnosno 11,21 puta manjeg kod dela Dalmacije i Like, do 2,27 odnosno 1,23 puta manjeg kod Severozapadne Hrvatske i Istočne Bosne. U njemu je život izgubila polovina svih stradalih civila Slavonije $(54,11 \%)$, dve petine iz Srema $(38,30 \%)$, trećina stradalih civila sa Banije $(32,73 \%)$, po četvrtina iz Severozapadne Hrvatske $(26,70 \%)$ i Bosanske Krajine $(23,27 \%)$, ali i minimalni delovi stradalih civila Like $(1,28 \%)$, dela Dalmacije $(3,49 \%)$ i Hercegovine $(5,57 \%)$.

Za Jevreje i Rome, koji su rasnim zakonima unapred bili određeni za uništenje, Jasenovac je predstavljao centralno mesto stradanja u kome je život izgubilo $78,08 \%$ stradalih Roma, odnosno 61,68\% stradalih Jevreja NDH. Masovni teror sprovođen nad srpskim narodom u NDH imao je sve odlike zločina genocida, a Jasenovac je imao istaknuto mesto u sprovođenju tog zločina, pošto je u njemu život izgubilo 23,24\% od svih stradalih civila srpske nacionalnosti iz NDH, čime je on postao primarno mesto njihovog stradanja. U Jasenovcu je život izgubilo $11,81 \%$ stradalih civila hrvatske nacionalnosti, 3,50\% civila muslimanske nacionalnosti, te 4,39\% stradalih civila pripadnika ostalih i nepoznatih nacionalnosti.

U devet od 12 regiona NDH Srbi su predstavljali najveći deo gubitaka pretrpljenih u logoru, svuda sa natpolovičnom većinom od 92,43\% u Bosanskoj Krajini i 91,85\% na Baniji, do 54,87\% u Sremu. Jevreji su u dva regiona bili najbrojniji među stradalima u Jasenovcu (Istočna Bosna 55,35\% i Severozapadna Hrvatska 36,21\%), dok su u jednom regionu (Gorski kotar sa hrvatskim pri- 
morjem) Romi činili 57,07\% gubitaka. Hrvati su u jednom regionu činili trećinu i u dva regiona po četvrtinu stradalih u Jasenovcu (Severozapadna Hrvatska (35,09\%), dok su Muslimani u jednom regionu predstavljali devetinu gubitaka pretrpljenih u logoru (Hercegovina 11,59\%).

Tri četvrtine u Jasenovcu stradalih Srba (74,61\%) poticalo je iz tri regiona (36,88\% iz Bosanske Krajine, 27,20\% iz Slavonije, 10,53\% sa Banije), uz 7,91\% iz Istočne Bosne i 5,89\% iz Srema, dok je učešće stradalih Srba iz ostalih sedam regiona bilo manje ili minimalno (Lika $0,28 \%$ ). Srbi iz tri regiona su imali nesrazmerno veće učešće u gubicima u Jasenovcu od zastupljenosti u nacionalnom korpusu, Slavonije 2,60 puta, Banije 2,04 puta i iz Bosanske Krajine 1,60 puta, dok je učešće u gubicima stradalih iz ostalih devet regiona bilo manje, od 1,15 puta Severozapadne Hrvatske, do 19,35 puta manjeg iz Like. U Jasenovcu je život izgubilo $55,54 \%$ od svih stradalih civila srpske nacionalnosti iz Slavonije, 33,99\% iz Severozapadne Hrvatske, 33,70\% sa Banije, 28,34\% iz Srema, 23,50\% Bosanske Krajine, 20,44\% iz Srednje Bosne, 15,02\% iz Istočne Bosne, dok je udeo stradalih u Jasenovcu u ostalih pet regiona bio daleko manji ili minimalan (Lika 0,89\%).

Polovinu svih Jevreja iz NDH stradalih u Jasenovcu predstavljali su pripadnici ove nacionalne zajednice iz Istočne Bosne (47,65\%), uz 21,27\% iz Severozapadne Hrvatske i 18,63\% Slavonije. Dok su iz Istočne Bosne gotovo svi Jevreji izgubili živote u Jasenovcu (90,74\%), od njihovih sunarodnika iz Slavonije i Severozapadne Hrvatske svega je 54,69\% odnosno 35,89\% stradalo u tom logoru. Od stradalih Roma u Jasenovcu 59,95\% je poticalo iz Slavonije, a u njemu je život izgubilo po četiri petine od svih stradalih Roma iz Slavonije, Srema i Severozapadne Hrvatske.

Jasenovac je NDH koristila za eliminaciju ,nepodobnih“ Hrvata iz svih njenih delova, s time što ih je 45,92\% poticalo iz Severozapadne Hrvatske i $26,70 \%$ iz Slavonije. U njemu je život izgubila četvrtina od svih stradalih civila hrvatske nacionalnosti sa Banije (26,45\%), 21,20\% iz Slavonije, 16,03\% iz severozapadne Hrvatske. Od stradalih Muslimana u Jasenovcu 43,22\% je poticalo iz Bosanske Krajine i 28,93\% iz Istočne Bosne, a u njemu je živote izgubilo 13,09\% od svih stradalih civila muslimanske nacionalnosti iz Bosanske Krajine, dok je udeo stradalih iz ostala tri regiona bio mali ili minimalan (Istočna Bosna 1,39\%).

\section{REFERENCE}

- Almuli, Jaša. Jevreji i Srbi u Jasenovcu. Beograd: Službeni glasnik, 2009.

- Antonić, Zdravko, ur. Jasenovac, zbornik radova IV međunarodne konferencije. Banja Luka: JUSP Donja Gradina, 2007.

- Benčić Adriana, Stipe Odak i Danijela Lučić, ur. Jasenovac manipulacije, kontroverze i povjesni revizionizam. Jasenovac: JUSP Jasenovac, 2018.

- Benčić Rimay, Tea, ur. Spomen područje Jasenovac - katalog-monografija. Jasenovac: JUSP Jasenovac, 2006.

- Benčić Rimay, Tea, ur. Jasenovac, žrtva je pojedinac - Poimenični popis žrtava koncentracijskog logora Jasenovac 1941.-1945.. Jasenovac: JUSP Jasenovac, 2007. 
- Cvetković, Dragan. „Koncentracijski logor Jasenovac i njegova uloga u uništavanju naroda NDH - izračun mogućeg broja žrtava na temelju djelimično revidiranog popisa 1964. godine“. U: Jasenovac manipulacije, kontroverze $i$ povjesni revizionizam. Urednici Adriana Benčić, Stipe Odak, Danijela Lučić, 171-219. Jasenovac: JUSP Jasenovac, 2018.

- Cvetković, Dragan. „Gubici pripadnika partizanskog pokreta sa teritorije Jugoslavije 1941-1945“. Doktorska disertacija, Univerzitet u Beogradu, Filozofski fakultet, Odeljenje za istoriju, 2016.

- Cvetković, Dragan. „Stradanje stanovništva NDH u logorima - numeričko određenje“. U: Logori, zatvori i prisilni rad u Hrvatskoj / Jugoslaviji 1941.1945., 1945-1951. Urednici Vladimir Geiger, Martina Grahek Ravančić i Marica Karakaš Obradov, 41-57. Zagreb: HIP, 2010.

- „Holokaust u NDH - numeričko određenje“. Istorija 20. veka, XXIX, br. 1, (2011), 163-182.

- Cvetković, Dragan. „Stradanja civila Nezavisne Države Hrvatske u logoru Jasenovac“. Tokovi istorije, br. 4, (2007), 153-168.

- Definitivni rezultati popisa stanovništva od 31.3.1931.godine knjiga I; Prisutno stanovništvo, broj kuća i domaćinstava. Beograd: Državna štamparija, 1937.

- Definitivni rezultati popisa stanovništva od 31. marta 1931. godine, knjiga II, Prisutno stanovništvo prema veroispovesti. Beograd: Državna štamparija, 1938.

- Demografska statistika, Stanovništvo predratne Jugoslavije po veroispovesti $i$ maternjem jeziku po popisu od 31-III-1931. god., pregled po srezovima. Beograd: Državni statistički ured Demokratske Federativne Jugoslavije, 1945.

- Demografska statistika, Stanovništvo po veroispovesti i maternjem jeziku po popisu od 31-III-1931. god., Hrvatska, pregled po opštinama. Beograd: Državni statistički ured Demokratske Federativne Jugoslavije, 1945.

- Demografska statistika, Stanovništvo po veroispovesti i maternjem jeziku po popisu od 31-III-1931. god., Bosna i Hercegovina, pregled po opštinama. Beograd: Državni statistički ured Demokratske Federativne Jugoslavije, 1945.

- Demografska statistika, Stanovništvo po veroispovesti i maternjem jeziku po popisu od 31-III-1931. god., Srbija sa Vojvodinom i Kosovo - Metohijom, pregled po opštinama. Beograd: Državni statistički ured Demokratske Federativne Jugoslavije, 1945.

- Geiger, Vladimir. „Ljudski gubici Hrvatske u Drugom svjetskom ratu koje su prouzročili „okupatori i njihovi pomagači“ Brojdbeni pokazatelji (procjene, izračuni, popisi)“. Časopis za suvremenu povijest, 43, br. 3, (2011), 699-749.

- Geiger, Vladimir. „Brojidbeni pokazatelji o žrtvama logora Jasenovac, 1941.1945. (procjene, izračuni, popisi)“. Časopis za suvremenu povijest, 45, br. 2 , (2013), 211-242.

- Graovac Igor, i Dragan Cvetković. Ljudski gubici Hrvatske 1941.-1945. godine: pitanja, primjeri, rezultati... . Zagreb: Dijalog, 2005.

- Goldstein, Slavko. Jasenovac - tragika, mitomanija, istina. Zagreb: Fraktura, 2016.

- Goldstein Slavko, i Ivo Goldstein. Jasenovac i Bleiburg nisu isto. Zagreb: Novi Liber, 2011 
- Halilbegović, Nihad. Bošnjaci u jasenovačkom logoru. Sarajevo: Vijeće kongresa bosanskih intelektualaca, 2006.

- Horvat Vladimir, Igor Vukić, Stipo Pilić i Blanka Matković. Jasenovački logori - istraživanja. Zagreb: Društvo Jasenovački logori, 2015.

- Kočović, Bogoljub. Žrtve Drugog svetskog rata u Jugoslaviji. London: Naše delo, 1985.

- Krestić Vasilije, i Mira Radojević, Jasenovac. Beograd: SANU, 2017.

- Kovačić, Davor. „Iskapanja na prostoru koncentracijskog logora Stara Gradiška neposredno poslije završetka Drugog svjetskog rata i procjene broja žrtava“. Scrinia Slavonica, br. 3, 2003, 500-520.

- Lajbenšperger, Nenad. „Presenting and Establishing the Number of Yugoslav Casualites of World War II from Liberation until 1951“. Токови историје, бр. 3 (2017), 143-164.

- Lengel-Krizman, Narcisa. Genocid nad Romima. Jasenovac-Zagreb: JSUP Jasenovac, 2003.

- Markoci Vladimir, i Vladimir Horvat. Ogoljela laž logora Jasenovac. Zagreb: Emil Čić, 2008.

- Mataušić, Nataša. Jasenovac 1941.-1945., Logor smrti i radni logor. Jasenovac-Zagreb: JUSP Jasenovac, 2003.

- Miletić, Antun. Koncentracioni logor Jasenovac, knjiga IV. Jagodina: Gambit, 2007.

- Miletić, Antun. Ubijeni u koncentracionom logoru Jasenovac 1941-1945. Jagodina: Gambit, 2011.

- Mirković, Jovan. Objavljeni izvori i literatura o jasenovačkim logorima. Banja Luka-Beograd: GrafoMark i MŽG, 2000.

- Motl Dejan, i Đorđe Mihovilović. Zaboravljeni. Knjiga o posljednjim jasenovačkim logorašima. Jasenovac - Zagreb: JUSP Jasenovac, 2015.

- Nikodijević, Dušan. „Prilog utvrđivanju broja žrtava sistema logora Jasenovac 1941. godine“, Godišnjak za istraživanje genocida, br. 8, (2016), 169-213.

- Nikodijević, Dušan. „Brojevi žrtava u koncentracionom logoru Jasenovac 1942. godine prema iskazima preživelih svedoka“. Godišnjak za istraživanje genocida, br. 9, (2017), 95-117.

- Nikodijević, Dušan. „Brojevi žrtava u koncentracionom logoru Stara Gradiška 1942. godine prema iskazima preživelih svedoka“, Godišnjak za istraživanje genocida, br. 10, (2018), 127-155.

- Vukić, Igor. Radni logor Jasenovac. Zagreb: Naklada Pavičić, 2018.

- Žerjavić, Vladimir. Gubici stanovništva Jugoslavije u Drugom svjetskom ratu. Zagreb: Jugoslavensko viktimološko društvo, 1989.

- Živanović, Srboljub. Jasenovac, odabrani radovi, članci, intervjui, govori $i$ diskusije. Urednik Todor Bjelkić. Beograd - London: Srpska knjiga, 2008.

- Žrtve rata 1941-1945 (rezultati popisa). Beograd: Savezni zavod za statistiku, 1966, reprint Beograd: Savezni zavod za statistiku, 1992. 
DRAGAN CVETKOVIĆ, PhD, Museum Adviser

Museum of Genocide Victims

Belgrade, Republic of Serbia

vecadzigy@yahoo.com

\section{GEOSTATISTIC ANALYSIS OF HUMAN LOSSES \\ IN THE JASENOVAC CONCENTRATION CAMP}

\section{Sumarry}

The paper is an attempt to show the role of the Jasenovac concentration camp in the destruction of peoples from different parts of the Independent State of Croatia (NDH) based on partially revised list „Victims of War 1941-1945” from 1964. On the basis of achieved results in the process of revision of the census list, a calculation of the total losses of the civilians of Yugoslavia, of those in the NDH and its regions, with particular focus on losses in the Jasenovac camp was made. The losses in Jasenovac were analyzed through the prism of the general losses of the civilian population of NDH during the war, in all its parts. They were all compared with the demographic structure of the population of the NDH and its regions.

Jasenovac camp system, was the largest concentration camp in the $\mathrm{NDH}$, where a quarter of all killed civilians in this territory lost their lives $(24.53 \%)$. The scope of the crimes committed in the Jasenovac camp clearly identify it as a destruction camp. The victims in Jasenovac were brought to the camp from all parts of the NDH. Most of the dead were originally from the two regions with which the camp was bordering, 30.60\% from Slavonia and $25.13 \%$ from Bosanska Krajina, with $12.62 \%$ of losses originating from Eastern Bosnia. The victims from 4 regions had a greater share in losses in Jasenovac than their representation in the population of NDH, Banija 2.25 times, Bosnian Krajina 2.14 times, Slavonia 2.13 times and Srem 1.19 times, while Kordun had equal share. The victims of the other $7 \mathrm{NDH}$ regions had much less participation in the losses in Jasenovac than their representation in the population, from 19.12 and 11.21 times lower in the part of Dalmatia and Lika, up to 2.27 and 1.23 times lower in Northwestern Croatia and Eastern Bosnia. Jasenovac was the site of the death of half of all killed Slavonia civilians (54.11\%), two fifths from Srem (38.30\%), one third of killed civilians from Banija (32.73\%), a quarter from Northwestern Croatia (26.70\% ) and Bosanska Krajina (23.27\%), but also minimal parts of the killed civilians from Lika (1.28\%), Dalmatia (3.49\%) and Herzegovina $(5.57 \%)$.

Jasenovac was the central place of death in the NDH, where $78.08 \%$ of all victims of the Roma lost their lives, $61.68 \%$ of the victims of the Jews, $23.24 \%$ of Serbian civilian victims, $11.81 \%$ of Croats, $3.50 \%$ of Muslims and $4.39 \%$ of members of other and unknown nationalities. In nine of the twelve 
NDH regions, Serbs accounted for the bulk of the loss of prisoners in the camp, everywhere with a predominant majority of $92.43 \%$ in the Bosnian Krajina and $91.85 \%$ in Banija, up to $54.87 \%$ in Srem, the Jews were majority in two regions (Eastern Bosnia 55,35\% i Northwest Croatia 36,21\%), and the Romas in one. Three-quarters of Serbs killed the Jasenovac (74.61\%) come from three regions (36.88\% from Bosanska Krajina, 27.20\% from Slavonia, 10.53\% from Banija). Of all Serb civilians victims from Slavonia, 55.54\% lost their lives in Jasenovac, as well as $33.99 \%$ of Serb civilian victims from Northwestern Croatia, $33.70 \%$ from Banija, 28.34\% from Srem, 23.50\% from Bosanska Krajina, while the share of victims of Jasenovac in the other seven regions was far smaller or minimal (Lika $0.89 \%$ ). Half of all Jews victims in Jasenovac were from Eastern Bosnia (47.65\%), with 21.27\% from Northwestern Croatia and $18.63 \%$ of Slavonia, while $12.45 \%$ were from the other nine regions. While in Eastern Bosnia almost all Jews lost their lives in Jasenovac (90.74\%), from Jews from Slavonia and Northwestern Croatia, 54.69\% and 35.89\% of them were killed in that camp. Of the dead Roma in Jasenovac, 59.95\% originated from Slavonia, where life was lost by four fifths of all the Romas victims from Slavonia, Srem and Northwestern Croatia. Of the Croats killed in Jasenovac, 45.92\% were from northwestern Croatia, while $43.22 \%$ of the Muslims killed in the camp were from the Bosnian Krajina.

KEYWORDS: Independent State of Croatia (NDH), civilians, concentration camp, Jasenovac, Serbs, Jews, Roma, Croats, Muslims, population, regions, losses, victims 